\title{
ÚVOD DO SYSTÉMU PRÁVNÍ OCHRANY DUŠEVNÍHO VLASTNICTVÍ VE STÁTĚ IZRAEL ${ }^{1}$
}

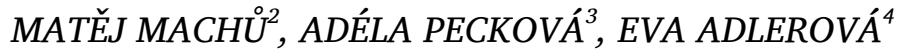

\begin{abstract}
ABSTRAKT
Článek se zabývá izraelským právním systémem s orientací na právní ochranu duševního vlastnictví. Článek postupuje od stručného představení vývoje izraelského práva s identifikací vlivů, které přispěly $k$ formování jeho současné podoby, až $k$ současné právní úpravě v oblasti práva smluvního, práva na ochranu výsledků technické tvůrčí činnosti jako je oblast práva patentového nebo práva vzorového a v závěru také oblasti ochrany práv na označení. Článek čerpá především z primárních zdrojů, kterými jsou právní předpisy Státu Izrael, jakožto $i$ z rozhodnutí izraelských soudů, které mají v rámci tamního systému nezastupitelnou roli při výkladu, ale také tvorbě práva.
\end{abstract}

1 Článek vznikl v rámci řešení úkolu grantového projektu Metropolitní univerzity Praha, o.p.s. IGS MUP E07-53 s názvem Ochrana technických řešení a práv na označení v mimoevropských zemích.

2 Mgr. Matěj Machů, Ph.D. je akademickým pracovníkem Metropolitní univerzity Praha a stálým členem katedry průmyslového vlastnictví zaměřujícím se na zahraniční právní systémy v oblasti ochrany duševního vlastnictví. Současně pracuje také jako patentový zástupce a specialista na právní ochranu duševního vlastnictví v advokátní kanceláři. Je autorem 2. kapitoly tohoto článku.

3 Mgr. Adéla Pecková je doktorandkou na katedře průmyslového vlastnictví Metropolitní univerzity Praha, kde se zabývá především právní ochranou technických řešení. Je autorkou 3. kapitoly tohoto článku a bodu 2.4 .

4 Mgr. Eva Adlerová je doktorandkou na katedře průmyslového vlastnictví Metropolitní univerzity Praha, kde se zabývá především ochranou práv na označení se zaměřením na common law systémy. Je autorkou 4. kapitoly tohoto článku. 


\title{
KLÍČOVÁ SLOVA
}

Izrael, izraelské právo, právo duševního vlastnictví, právo průmyslového vlastnictví, srovnávací právo

\begin{abstract}
Presented paper deals with the Israeli legal system with a focus on legal protection of intellectual property. Article progresses from a brief presentation of the history of Israeli law with identification of influences that contributed to shaping of its current form, to the present day contract law, legal protection of results of technical creative activity such as patent law or design law and in the end also trademark protection. Paper is based mainly on primary sources, which are the laws of the State of Israel, as well as the Israeli case law, which is irreplaceable within the Israeli system not only in the legal interpretation but in the creation of law as well.
\end{abstract}

\section{KEYWORDS}

Israel, Israeli law, intellectual property law, industrial property law, comparative law

\section{1. ÚVOD}

Stát Izrael je bezpochyby významným hráčem na poli duševního vlastnictví, jelikož patří mezi země $s$ významným podílem podaných přihlášek vynálezů, v čemž převyšuje většinu evropských zemí. Současně je také domovem mnoha práv na označení, se kterými se v současné době setkáváme takřka po celém světě. Toto jsou však pouze některá z hledisek, která činí Stát Izrael zajímavým z pohledu českého odborného čtenáře. Prioritní je zde totiž bezesporu hledisko nárůstu obchodní výměny mezi Českou republikou a Státem Izrael, které vychází i z dlouhodobé spolupráce na vládní úrovni s cílem podpořit nejen vzájemnou obchodní, ale také vědeckou a studijní činnost. Nový izraelský velvyslanec Daniel Meron sám označil za svůj hlavní úkol v České republice rozvoj ekonomických vztahů a 
prohloubení spolupráce $\mathrm{v}$ oblasti výzkumu a vývoje špičkových technologií. ${ }^{5}$

Za zmínku jistě stojí také Asociační dohoda mezi členskými státy Evropské Unie a Státem Izrael ${ }^{6}$, která směřuje $\mathrm{k}$ odstranění některých překážek v obchodním styku, což se v důsledku projevuje i v zájmu izraelské společnosti na myšlence budoucího připojení Izraele k Evropské Unii, jakkoli nereálné se to může ze současného pohledu zdát.

$S$ ohledem na tyto skutečnosti je třeba tedy věnovat pozornost také lepšímu obeznámení se systémem práva na ochranu duševního vlastnictví v Izraeli, které je klíčovým pro efektivní uplatnění práv českých nebo obecněji také evropských podniků na izraelském trhu. Bohužel však je množství dostupné literatury $\mathrm{k}$ této problematice soustředěno bud' na oblast mezinárodního práva, nebo práva obchodního a práva duševního vlastnictví, ale zpravidla pouze z pohledu právních systémů s anglo-americkou právní tradicí, který není vždy zcela přenosným na tradiční systémy kontinentální.

Tento článek si proto klade za cíl, přiblížit české odborné veřejnosti obecný systém práva ve Státě Izrael s následným podrobnějším náhledem do problematiky ochrany duševního vlastnictví zejména oblasti průmyslových práv, jehož předměty jsou mimo jiné také technická řešení a design či práva na označení s důrazem na jejich neformální ochranu prostřednictvím práva nekalé soutěže, jelikož ta je bezesporu nejčastějším zpưsobem jejího uplatňování ze strany zahraničních subjektů.

Článek nepředstavuje studii $\mathrm{v}$ rámci oboru srovnávacího práva, avšak v některých dílčích oblastech je využívána komparace zejména s právem českým pro lepší pochopení řešené problematiky z pohledu českého čtenáře. S výjimkou vybraných částí práva smluvního, jakou je například institut

5 Viz Články. Lidovky.cz: Rozhovor s velvyslancem Státu Izrael Danielem Meronem pro deník lidovky.cz [online]. Publikováno: 19.3.2017. [cit. 27.3.2017]. Dostupné z: http://byznys.lidovky.cz/skoro-vsechny-taxiky-v-izraeli-jsou-skodovky-rika-novyvelvyslanec-1gy-/firmy-trhy.aspx?c = A170317_172457_firmy-trhy_pave

${ }^{6}$ Viz Ministerstvo zahraničních věcí České republiky. Asociační dohoda mezi členskými státy Evropské unie a Státem Izrael [online]. [cit. 01.01.2017]. Dostupné z: http://www.mzv.cz/ public/50/a0/79/161530_14901_asso_agree_en.pdf 
mimosmluvních občanských nebo obchodních deliktů, je zcela nesporná souvislost mezi danými oblastmi v právu izraelském a českém a jejich srovnání tedy spočívá na jednotném základu dle společného záměru zákonodárce v obou právních systémech, jakým je u př́kladu práva patentového tzv. společenská smlouva ${ }^{7}$ mezi přihlašovatelem a státem, kdy je přihlašovateli uděleno výhradní právo $\mathrm{k}$ využití daného technického řešení na omezenou dobu za cenu toho, že se jeho vynález stává součástí techniky.

\section{2. ÚVOD DO IZRAELSKÉHO PRÁVNÍHO SYSTÉMU}

Izraelské právo spočívá $\mathrm{v}$ počátcích svého vývoje na značně odlišném základu od práva českého, což se samozřejmě v důsledku projevuje až do současné doby. Pokud hovoříme o izraelském právu, je v rámci tohoto článku míněno primárně právo Státu Izrael. Historický základ izraelského práva sahá ovšem dále než do roku 1948, tedy do období před vyhlášením samostatného státu.

Rozdělením, které je možné $\mathrm{v}$ této době učinit, je také odlišení práva země, tedy území Osmanské řiše s pozdějším převzetím moci britskou koloniální správou a právem izraelského národa, pod které můžeme zařadit právo židovské společně s obsažnou skupinou práv zemí, z nichž velká část židovské imigrace do oblasti dnešní Izraele přicházela. Všechny tyto dílčí vlivy se poté společně podílely na vzniku značně unikátního právního systému, kterým izraelské právo bezpochyby i v současnosti je.

Izraelskou právní kulturou a prameny izraelského práva se článek zabývá níže. $V$ úvodu do izraelského právního systému je ovšem, a to především s ohledem na význam soudní role při výkladu, ale i tvorbě práva, namístě představit izraelský soudní systém, který se v mnoha aspektech odlišuje od soudní soustavy v České republice.

Soudní soustava ve Státě Izrael sestává ze základního členění na soudy obecné a soudy zvláštní (tzv. tribunály). Obecné soudy v Izraeli dělíme na

\footnotetext{
7 Tento filozofický termín je zde užit v přeneseném významu, kdy vlastníku patentu nepř́ísluší jeho práva bez dalšího, ale jejich přiznání je podmíněno právě oním zveřejněním vynálezu, u kterého by nemělo docházet k zamlčení žádných podstatných znaků vynálezu.
} 
soudy magistrátnî ${ }^{8}$ a oblastnî ${ }^{9}$, nad kterými se poté nachází Nejvyšší soud v Jeruzalémě. Oproti České republice zde ovšem chybí soudy vrchní a také není zrrízen zvláštní soud pro věci správní jako je tomu v případě Nejvyššího správního soudu v Brně.

Nejvyšší soud v Jeruzalémě představuje na základě své úlohy vyplývající ze zákona o soudnictví z roku $1957^{10}$, zákona o občanském právu procesním z roku 1966 a zákona o pravidlech High Court of Justice z roku 1984 současně soud odvolací a nejvyšší1 ${ }^{11}$ či ústavní. ${ }^{12,13}$ U Nejvyššího soudu v Jeruzalémě je také třeba zmínit jeho význam pro soudcovské (precedenční) právo. $\mathrm{V}$ případě, že se $\mathrm{v}$ řízení před nejvyšším soudem projednává věc, v níž Nejvyšší soud rozhoduje jako soud odvolací nebo také soud první instance s tím, že bylo dosaženo rozhodnutí, které se odklání od starší rozhodovací praxe, může nejvyšší soud, pokud tak uzná za vhodné, nařídit také další slyšení, u kterého bude př́tomen širší senát soudců. Institutu

8 Ve Státě Izrael se nachází celkem 20 magistrátních soudů., které je možné svou povahou a příslušností analogicky chápat jako soudy okresní (případně soudy obvodní) v České republice. V překladu z hebrejského jazyka je nepřesnějším označením magistrátních soudů soudy smírčí.

9 Ve Státě Izrael se nachází celkem 5 oblastních soudi̊. V analogii k České republice představují soudy krajské (případně Městský soud v Praze).

10 Pozn. Izraelské právní předpisy jsou označovány odlišně od předpisů českých. Dílčí předpisy nejsou označeny příslušným číslem a rokem, ale pouze slovním názvem s příslušným rokem.

11 Ve smyslu High Court of Justice známého spíše ze soudního systému ve Spojeném království (v hebrejském znění doslova soud nejvyšší spravedlnosti) představuje soud, který je příslušný posuzovat například zákonnost rozhodnutí a nařízení státních orgánů včetně zákonodárného shromáždění. V této roli také představuje první instanci. Viz GOLDSTEIN, Stephen; BAUM, Ido; KARAKO-EYAL, Nili; MERIN, Yuval. Civil Procedure in Israel. New York: Wolters Kluwer, 2013. s. 55 ISBN: 90-411-5163-X.

12 S ohledem na neexistenci formální ústavy, zpravidla nehovoříme o Nejvyšším soudu v Jeruzalémě jako o soudu ústavním, ale určitou roli ústavního soudu přesto zastává, jelikož je příslušný $\mathrm{k}$ posuzování souladu předpisů vydaných zákonodárným shromážděním se základními zákony. Viz Rozhodnutí Nejvyššího soudu v Jeruzalémě 6821/93 United Mizrachi Bank Ltd. proti Migdal Cooperative Village In: Nevo [online]. [cit. 27. 3. 2017] Dostupné z: www.nevo.co.il/Psika_word/elyon/PADI-NH-4-221-L.doc

13 Model nejvyššího soudu je zde tedy nejbližší všeobecnému difúznímu modelu ústavního soudnictví. Podrobněji o ústavním soudnictví v zahraničí hovoří BLAHOŽ, Jozef; BALEŠ, Vladimír; KLÍMA, Karel. Srovnávací ústavní právo. 5. vydání. Praha: Wolters Kluwer, 2015. ISBN 978-80-7478-687-7. 
dalšího slyšení je tedy užíváno u rozhodnutí, která mají velkou důležitost pro další vývoj izraelského práva.

Pozice prvoinstančních soudů zpravidla ${ }^{14}$ tedy připadá soudům magistrátním a oblastním. Všechny tři stupně soudů jsou věcně př́slušné pro řízení ve věcech občanskoprávních, kam spadá i většina sporů v oblasti duševního vlastnictví. Zda bude daná věc projednávána před soudem magistrátním nebo oblastním rozhoduje výše žalované částky, kdy oblastnímu soudu připadají teprve spory přesahující částku jeden milion NIS (nový izraelský šekel). Oblastní soudy mají ovšem výlučnou pravomoc jednat jako soudy prvního stupně ve věcech týkajících se průmyslového vlastnictví jako jsou patenty, ochranné známky, průmyslové vzory, označení původu a zeměpisná označení. Ve věcech týkajících se oblastí autorského práva, obchodního tajemství nebo nekalé soutěže mohou rozhodovat i soudy magistrátní.

Magistrátní soudy také zastávají funkci soudů pro malé spory označované v rámci anglo-amerického systému jako small claim courts. V Izraeli se zde jedná o spory nepřesahující hranici žalované částky osm tisíc NIS. Existence soudů pro malé spory je založena na minimalizaci soudních výloh pro žalobce (a př́ípadně také pro žalovaného), kdy zahájení a vedení běžného sporu u magistrátního soudu by bylo spojeno s vyššími náklady ve formě soudních poplatků, případně také nákladů na zastoupení, což vede $\mathrm{k}$ situaci, kdy je žalobce demotivován k podání návrhu na zahájení takového bagatelního sporu. Pro zachování spravedlnosti byly tedy tyto soudy (soudní senáty) zřízeny. Oproti běžnému řízení se odlišují nejen v otázkách finančních, ale také $\mathrm{v}$ poněkud zjednodušené procesní stránce, kde vystupuje pouze jediný soudce (označovaný také jako rozhodce), řízení je vedeno $\mathrm{s}$ nižšími nároky na formalitu a vzhledem $\mathrm{k}$ absenci advokáta ${ }^{15}$ soud připouští i důkazy, které by $\mathrm{v}$ běžném rrízení uznány nebyly. Je třeba mít na paměti, že řízení nemůže být před tímto soudem zahájeno na návrh obchodní korporace, ale pouze fyzické osoby. Proti obchodní korporaci však může být žaloba vedena. Pro řízení je také stanoven roční limit nejvýše pěti

\footnotetext{
14 Výjimku zde tvoří Nejvyšší soud v Jeruzalémě v roli High Court of Justice.

15 Zastoupení advokátem je zde výjimečné a závisí na jeho schválení soudem.
} 
žalob pro jediného žalobce. Absence advokáta také stanovuje vyšetřovací povinnost soudce, který tímto způsobem obtíže spojené s nedostatečným návrhem zmírňuje. Díky částečně rozhodčí povaze soudu s větším zapojením soudce do věcné stránky řízení, je obvykle rozhodnutí vyneseno již po prvním jednání. $\mathrm{V}$ případě, že jedna ze stran s rozhodnutím nesouhlasí, je přípustné odvolání $\mathrm{k}$ oblastnímu soudu, v případě, že oblastní soud takové odvolání přijme. ${ }^{16}$

Po boku soudů obecných také v Izraeli fungují soudy zvláštní neboli takzvané tribunály. Tyto tribunály jsou specializovanými soudy pro některé oblasti práva jako tribunály pracovní, které existují ve dvoustupňovém systému jako tribunály oblastní a Národní pracovní tribunál. Obdobně fungují také vojenské tribunály s druhoinstančním Vojenským stížnostním tribunálem. Do této kategorie spadají dále také soudy rodinné vzhledem k personalitě práva rodinného, proto existují soudy rabínské či církevní. $\mathrm{V}$ jejich případě není zřízen zvláštní druhoinstanční soud a odvolání je tedy směřováno k obecným soudům oblastním.

Příbuznost izraelského procesního práva, jak už bylo řečeno, je i přes dřívější aplikaci práva britského bližší úpravě americké. Přesto zde nacházíme také prvky smíšeného právního systému, kdy se určité aspekty procesního práva přibližují více kontinentální právní tradici ${ }^{17}$. Vyšetřovací pravomoc soudce byla již zmíněna $\mathrm{v}$ př́padě soudů pro malé spory, a ačkoli ne $\mathrm{v}$ takové míře, je uplatňována $\mathrm{v}$ rámci běžného řízení před obecnými soudy. Na rozdíl od některých systémů anglo-amerických zde také není v soudních řízeních uplatňována porota.

\subsection{PRÁVNÍ KULTURA IZRAELSKÉHO PRÁVA A PRAMENY PRÁVA}

Historický vývoj práva, který byl ve stručnosti představen výše, samozřejmě určuje samotnou právní kulturu izraelského práva. Jak již bylo zmíněno, nejčastěji je izraelský systém řazen mezi tzv. systémy smíšené či hybridní, a to na základě spojení vlivu kontinentální i anglo-americké právní

${ }^{16}$ Viz CASPI, Zvi. Small Claim Court. In KAPLAN, Alon (general editor) a kol. Israeli Business Law. Haag: Kluwer Law International, 1996. s. 245-247 ISBN 90-411-0323-6.

17 Viz GOLDSTEIN, Stephen; BAUM, Ido; KARAKO-EYAL, Nili; MERIN, Yuval. Civil Procedure in Israel. New York: Wolters Kluwer, 2013. s. 23-26 ISBN: 90-411-5163-X. 
tradice, kdy jejich spojením není možné izraelské právo jednoznačně podřadit pod jednu z těchto kategorií. S podobným charakterem práva se však nesetkáváme výhradně v Izraeli, za všechny je zde možné jmenovat právo filipínské, které je směsicí práva španělského a amerického ${ }^{18}$ či právo kanadské provincie Quebec s vlivy francouzskými a anglickými.

Nejtypičtějším prvkem kontinentální právní tradice je kodex soukromého práva zpravidla označovaný jako občanský zákoník. S tímto se v současné době v Izraeli nesetkáváme, ovšem již od počátku vzniku Státu Izrael existuje snaha o jeho vytvoření. Nedávný pokrok v přípravě občanského zákoníku se tedy jeví tak, že by aktuální návrh skutečně mohl vstoupit v platnost v blízké budoucnosti. Navzdory tomu, že se občanský zákoník jeví jako jednoznačný př́íklon $\mathrm{k}$ právu kontinentálnímu, z návrhu jeho znění je patrné, že by jím nebyla nijak narušena funkce soudcovského (precedenčního) práva, jelikož se zde jedná spíše o seskupení existující roztříšěné oblasti občanského práva sestávající z mnoha dílčích předpisů do jediného kodexu. Izraelský prrístup $\mathrm{k}$ přípravě občanského zákoníku tedy připomíná více model švýcarský než český, a to uplatněním teorie mezer práva, která je více kompatibilní s právním modelem common law.

Charakter izraelského práva je také možné odvozovat od jeho ústavního modelu. Jak již bylo zmíněno výše, Stát Izrael formálně ucelenou ústavu nikdy nepřijal, a to přestože je zákonodárné shromáždění oprávněno takovou ústavu přijmout. Roli ústavy zde zastupují tzv. základní zákony, které Shromáždění přijímá v podobě, která má zůstávat neměnná a pro přijetí takového základního zákona je vyžadována většina všech hlasů v rámci Shromáždění. Tyto základní zákony však nepokrývají celou šíri běžného ústavního práva. Přesto řadu ústavních práv občanů Státu Izrael obsahují.

Diskutuje se ovšem také spor, zda by se současné Shromáždění mělo snažit o přijetí ústavy. Nejvyšší soud a především Aharon Barak ${ }^{19}$ ve svém rozhodnutí deklaroval názor, který se posléze stal i v rámci odborné ve-

${ }^{18}$ Viz MACHŮ, Matěj. Smíšené právní systémy a právo duševního vlastnictví: Systém práva duševního vlastnictví na Filipínách. Acta MUP - Právní ochrana duševního vlastnictví. Praha: Metropolitan University Prague Press, č. 1/2014.

19 Aharon Barak byl jedním z nejvýznamnějších autorit zejména v oblasti izraelského ústavního práva a působil jako soudce a následně předseda Nejvyššího soudu v Jeruzalémě. 
řejnosti široce akceptovaným, a to, že základní zákony samy již znamenaly přeměnu Státu Izrael na konstituční (ústavní) demokracii a že i další základní zákony mají být pojímány jako zákony ústavní a současně podpořil úlohu zákonodárného shromáždění jako orgánu podřízeného základním zákonům a určil právo nejvyššího soudu $\mathrm{k}$ přezkumu Shromážděním vydávané legislativy z pohledu ústavního, jak již bylo zmíněno výše. ${ }^{20}$ Tuto myšlenku podporuje i prohlášení, které zákonodárné shromáždění učinilo $\mathrm{v}$ roce 1950, kterým byla završena diskuze týkající se přípravy první ústavy, které hovoři o tom, že ústava bude připravována kapitolu po kapitole tak, že každá bude představovat vlastní zákon. ${ }^{21}$

Mimo roli základních zákonů jako určitého typu ústavního práva byly základní způsoby fungování vyjádřeny již v britském předpisu Palestine Order in Council z roku 1922, který stanovoval, že soudy mají uplatňovat právo v souladu s účinným osmanským právem na území mandátní Palestiny s tím, že další právní normy mohou být na toho území vztahovány prostřednictvím předpisů a nařízení. Současně je také třeba ctít podstatu common law a anglické zásady ekvity s dưrazem na vývoj anglické soudní praxe.

Obdobné ustanovení bylo posléze převzato i do právního systému Státu Izrael po vyhlášení nezávislosti dle předpisu o právu a správě z roku 1948, který inkorporoval přecházející anglické právo účinné na jeho území do nového právního řádu. Osmanské právo se tímto zpưsobem promítalo v izraelském právu ještě mnoho let po vytvoření samostatného státu. Anglické právo, které je zde zmiňováno, nebylo právo specifické pouze pro oblast mandátní Palestiny, ale jednalo se o právo, které bylo platné a účinné napříč britským impériem. Do současné doby tak v Izraeli existuje např́ílad „zákon o průmyslových vzorech“ z roku 1928 nebo donedávné doby účinný autorský zákon. O těchto právních předpisech se dále zmiňují i následující kapitoly tohoto článku.

20 Viz Rozhodnutí Nejvyššího soudu v Jeruzalémě 6821/93 United Mizrachi Bank Ltd. proti Migdal Cooperative Village In: Nevo [online]. [cit. 27. 3. 2017] Dostupné z: www.nevo.co.il/Psika_word/elyon/PADI-NH-4-221-L.doc

${ }^{21}$ Viz BAKER, Henry E. Legal System of Israel. Jeruzalém: Israel Universities Press, 1968. s. 11 
V otázce pramenů práva se projevil také zákon Základy práva z roku 1980 (Foundations of Law), který pozměnil a rozšíril tyto prameny mimo právo zákonné a soudní také na principy svobody, spravedlnosti, ekvity a pořádku dle izraelského odkazu. Toto ustanovení hraje významnou roli v možnosti uplatnění židovského práva v rámci občanskoprávního systému. Stejně tak podpořil tento zákon aplikaci obchodních zvyklostí vycházejících zejména z tradic právních systémů common law.

Jak je patrné již z výše citovaných právních předpisů, hraje v rámci práva izraelského významnou úlohu, také právo soudcovské. Izrael je jako země s výraznou úlohou anglo-amerického typu práva vázán zásadou stare decisis, a to zejména vzhledem k judikatuře nejvyššího soudu. Sám nejvyšší soud není starší judikaturou vázán, ačkoli obvykle neformálně taková rozhodnutí ve své praxi užívá, objevují se i rozhodnutí, která ji zcela ignorují. O tomto svědčí zejména rozhodnutí v otázce aplikace bezdůvodného obohacení v oblasti práva nekalé soutěže a duševního vlastnictví. ${ }^{22}$ Zde se nejedná, jak by se mohlo zdát, o rozhodnutí excesivní, přestože není starší judikaturou podpořeno, ale významný precedens, na kterém pracovala řada soudců a v rámci kterého se jim podařilo vytvořit významný právní institut. Tomuto rozhodnutí se podrobněji věnuje poslední kapitola tohoto článku.

Rovněž se na formování práva podílí i židovská tradice a židovské právo. Přestože je jeho formální projev v rámci izraelského práva pouze minimální, jedná se o určité měřítko, kterým se Shromáždění i soudy řídí. Za tento pohled na vývoj izraelského práva se zasloužil i bývalý předseda Nejvyššího soudu Meir Shamgar, který zásady, na nichž je židovské právo postaveno, převáděl i do aplikace $\mathrm{v}$ rámci izraelského práva soukromého. ${ }^{23}$ Podobná aplikace židovského práva však představuje také určitý problém pro izraelské soudce či právníky, kteři obvykle nejsou tohoto práva znalí ${ }^{24}$. Stejně tak z židovského práva byla přejata řada právních pojmů, což bylo

22 Viz Rozhodnutí Nejvyššího soudu v Jeruzalémě 5768/94 A.Sh.I.R. Importation Manufacture and Distribution et al. proti Forum Accessories and Consumer Products et al. In: Nejvyšší soud $\mathrm{v}$ Jeruzalémě [online]. [cit. 27. 3. 2017] Dostupné z: http://elyon1 .court.gov.il/files/94/680/057/G04/94057680.g04.pdf

${ }^{23}$ Viz Rozhodnutí Nejvyššího soudu v Jeruzalémě 513/89 Interlego S.A. proti Exin Lines Bros. S.A., et al. In: Nevo [online]. [cit. 27. 3. 2017] Dostupné z: www.nevo.co.il/ Psika_word/elyon/PADI-NG-4-133-L.doc 
zapříčiněno zejména tím, že hebrejský jazyk byl až do doby vyhlášení Státu Izrael jazykem spíše rituálním či liturgickým, který se v běžné řeči neužíval. Proto bylo po zavedení hebrejštiny jako úředního jazyka třeba tento jazyk přestavit do role jazyka běžného, čímž v něm vznikla řada slov přejatých z jiných jazyků, zejména jazyka anglického. Pro právní pojmy tedy nebylo jiného zdroje než právě práva židovského. ${ }^{25}$

Při porovnání vývoje dílčích prvků izraelské právní úpravy v čase můžeme pozorovat také určité vývojové změny ve vztahu k vlastnímu určení typu práva $\mathrm{z}$ hlediska právní kultury. Počáteční období bylo jednoznačně formováno prostřednictvím práva anglického. Nejen tím, že byla britská úprava převzata do nového právního systému, ale také proto že izraelské soudnictví po mnoho let blíže následovalo vývoj precedenčních rozhodnutí anglických soudů.

Určitý obrat poté nacházíme v období šedesátých let dvacátého století, kdy se izraelské soudy začínají postupně více zabývat také soudní praxí ve Spojených státech. ${ }^{26}$ Tento prŕklon k právu americkému přetrvává i v současné době, jak dobře dokresluje příprava nového autorského zákona, který se zbavil určitých prvků typických pro právo anglické a nahradil je pojmy a principy známými z práva amerického. Běžné poté je, že izraelské soudy při svém rozhodování často odkazují na předchozí judikaturu amerických soudů. ${ }^{27}$ Americká judikatura tedy tvoří jeden $\mathrm{z}$ neoficiálních pramenů izraelského práva. To ovšem neznamená, že by americká praxe byla ve všech ohledech následována. ${ }^{28}$

${ }^{24}$ Viz SHACHAR, Yoram. History and Sources of Israeli Law. In SHAPIRA, Amos. Introduction to the Law of Israel. Haag: Kluwer, 1995. ISBN 9065448357.

${ }^{25}$ Př́́kladem může být výraz nezikin, který označuje pojem mimosmluvních civilních deliktů v oblasti práva židovského i izraelského. Z pouhého znění tedy není možné rozeznat, kterého typu práva se $\mathrm{v}$ daném užití týká.

${ }^{26}$ Viz Rozhodnutí Nejvyššího soudu v Jeruzalémě 723/74 Israel Electric Company Ltd. proti Ha'aretz Newspaper Ltd In: Nejvyšší soud v Jeruzalémě [online]. [cit. 27. 3. 2017] Dostupné z: http://elyon1.court.gov.il/files_eng/74/230/007/Z01/74007230.z01.pdf

${ }^{27}$ Viz Rozhodnutí Nejvyššího soudu v Jeruzalémě 14/86 La'or proti The Israel Film and Theater Council In: Lawdata.co.il [online]. [cit. 27. 3. 2017] Dostupné z: http://www. lawdata.co.il/printDoc.asp $? \mathrm{c}=566490$ \&mador $=$ psak\&IskurHokIndx $=$ \&IskurHokSeif $=$ \&note $=\& \mathrm{dt}=1488844875000$ 


\subsection{SMLUVNÍ PRÁVO A JEHO VÝZNAM PRO OBLAST OCHRANY DUŠEVNÍHO VLASTNICTVÍ}

Izraelské smluvní právo představuje součást práva obchodního a je postaveno na dvou pilírích, které představuje princip svobody podnikání a smluvní volnosti. S ohledem na absenci jednotné kodifikace existuje řada právních předpisů, které pokrývají takřka celou šíri práva obchodního včetně norem vztahujících se ke smluvním nebo kvazi-smluvním vztahům, případně dalším obchodním vztahům či náhradám za porušení smluvních povinností. Přesto zde velkou roli, jak již vyplývá i z výše definované právní kultury, zastává také právo nebo jeho výklad tvořený soudy. Velká část izraelského smluvního práva je odvozena od práva anglického ${ }^{29}$, dílčí aspekty však $\mathrm{v}$ průběhu tvorby vlastního práva po vyhlášení nezávislosti Státu Izrael nacházejí inspiraci i v dalších právních systémech jako v právu německém či americkém. ${ }^{30}$

$\mathrm{V}$ nedávném období došlo $\mathrm{v}$ této právní oblasti $\mathrm{k}$ významným změnám a úpravám, at již prostřednictvím legislativních novelizací či soudní praxí. Tyto změny se týkaly především bezdůvodného obohacení či výkladu smluv a výrazným zpơsobem se také projevily i v oblasti duševního vlastnictví. Bezdůvodné obohacení, které bylo dřive aplikováno pouze doplňkově v žalobách ve věcech vymáhání práv z duševního vlastnictví, se nyní stává určitým nezávislým nástrojem ochrany práv, které nejsou přiřaditelné pod ochranu jiným právním institutem, jako jsou například designy nezapsané v rejstř́iku průmyslových vzorů. Změny v oblasti výkladu smluv mají také vztah i k právu duševního vlastnictví, a to především v otázkách smluv týkajících se převodu práv či smluv licenčních.

Smluvní právo, jak již bylo zmíněno, není sdruženo do jediného kodexu, a to ani v podobě obdobné právu americkému. Veškerá úprava je rozdělena

${ }^{28}$ Kupř́kladu oblast práva na ochranu osobnosti se v Izraeli zcela odklonila od dříve uplatňovaného amerického př́stupu a posunula se spíše směrem k právu židovskému.

${ }^{29}$ Viz BIN-NUN, Ariel. The Law of the State of Israel. Jeruzalém: Rubin Mass, 1990. s. 130 ISBN: 978-9650901127.

${ }^{30}$ Viz PALMER, Vernon. Mixed Jurisdictions Worldwide: The Third Legal Family. 2. vydání. New York: Cambridge University Press, 2014. s. 88 ISBN: 978-0521768573. 
do řady vzájemně provázaných norem. Nejdůležitějším předpisem je zákon o smlouvách z roku 1973, který upravuje obecné náležitosti smluvního práva, na které dále navazují zvláštní zákony dle jednotlivých typů smluvních závazků, a to jak v podobě smluv o koupi, zastoupení nebo ručení, tak i dalších aspektů jako způsobů nápravy porušení smluvních či kvazi-smluvních závazků včetně občanských mimosmluvních deliktů takzvaných tort., které jsou typickým prvkem vlivu anglo-americké právní tradice na právo izraelské a hovoříme o nich dále především $\mathrm{v}$ souvislosti $\mathrm{s}$ předpisem o občanských mimosmluvních deliktech a zákonem o obchodních mimosmluvních deliktech. Na rozdíl od práva amerického se tort v Izraeli považují za součást práva smluvního, ačkoli se jedná o delikty mimosmluvní.

Kontinentální právní tradice označení tort nebo jemu přímou paralelu nezná. Jedná se o konkrétní porušení povinnosti, která není založena smlouvou, proto zde hovoříme o mimosmluvních deliktech. V právu českém se setkáváme s delikty dle občanského zákoníku, které bychom mohli, byt ne zcela přesně, přirovnat $\mathrm{k}$ těmto mimosmluvním deliktům dle práva izraelského. I v tomto př́ípadě se jedná o delikt vyplývající z porušení povinnosti nezaložené smlouvou, ale povinnost, která je definována přímo zákonem (obligationis ex delicto).

Právo občanských (a obchodních) mimosmluvních deliktů má své počátky $\mathrm{v}$ právu římském stejně jako delikty definované $\mathrm{v}$ rámci práva kontinentálního. Kontinentální přístup ve svém vývoji zaznamenal dva zásadní směry deliktního práva, a to typ francouzský a německý. Francouzský typ byl vytvořen v rámci Code Civil a obsahoval obecnější a také stručnější přístup především díky existenci generální klauzule. Německý typ deliktního práva byl založen více kazuisticky s řadou skutkových podstat, které byly za delikty považovány. Tímto se německý model nejvíce přibližuje právě právu římskému. ${ }^{31}$

$\mathrm{Z}$ tohoto pohledu je zřejmé, že anglo-americký přistup k deliktnímu právu je římskému vzoru ještě bližší, když rozpracovává jednotlivé skut-

${ }^{31}$ Viz LUNNEY, Mark; OLIPHANT, Ken. Tort Law: Text and Materials. 5. vydání. Oxford: Oxford University Press, 2013. s. 1 - 2 ISBN: 978-0199655380. 
kové podstaty nejen $\mathrm{v}$ rámci jediného kodexu, ale i napříč dalšími právními předpisy a do jisté míry tak vytváří celý ekosystém tort. Tento právní model nacházíme nejen v právu Spojených států amerických či právu anglickém, ale vyskytuje se i v dalších právních systémech založených na common law jako je právo kanadské či australské a nejinak je tomu i ve Státě Izrael. Stejně jako kontinentální právní tradice není v této oblasti zcela jednotná, když se zde setkáváme s rozdílnými přístupy, jak již bylo nastíněno výše, není homogenní ani tradice anglo-americká. Přestože izraelské právo vychází ve svých počátcích z práva britského, je tedy zaměřeno podobně jako některé země Commonwealth, kupříkladu Austrálie, v následném vývoji se přiklání více $\mathrm{k}$ právu americkému, ve kterém se mnoha ohledech inspirovala i např́lklad Kanada.

Tort je tedy, jak již bylo zmíněno, jednání způsobující škodu druhé straně a zakládající tak nárok na náhradu této škody. Na základě toho jsou tyto delikty blízké i oblasti trestního práva a za určitých okolností mohou nést i trestněprávní následky. Jejich účelem však primárně není trestání škůdce, ale poskytnutí spravedlivé náhrady poškozenému a odrazení od podobného jednání v budoucnu.

Připravovaný občanský zákoník by měl převzít také sjednocující úlohu pro nyní roztřrištěnou úpravu v oblasti smluvního práva. Dle aktuálního návrhu je zřejmé, že kodifikace nebude přinášet do této oblasti výrazné změny, ale zasadí se o určité zjednodušení. ${ }^{32}$ Nezměněno zůstává také základní pojetí smlouvy jako objektivního projevu vůle, který je právem vynutitelný. ${ }^{33}$ Naopak ale představí také komplexněji upravené principy smluvního práva, což se může projevit v aplikaci starší judikatury přímo v normativní podobě nového systému.

Zvláštním zákonem vůči zákonu o smlouvách, který je nejvýznamnější také v oblasti duševního vlastnictví, je zákon o kupních smlouvách z roku 1968. Tento zákon z velké části vychází z mezinárodního jednotného záko-

${ }^{32}$ Podrobněji o izraelském občanském zákoníku pojednává SIEHR, Kurt; ZIMMERMANN, Reinhard. The Draft Civil Code for Israel in Comparative Perspective. Tübingen: Mohr Siebeck, 2008. ISBN 978-3-16-149590-8.

${ }^{33}$ Viz SHALEV, Gabriela; LERER, Lynn. Contract Law in Israel. Alphen aan den Rijn: Kluwer Law International, 2014. s. 23-26, 37 a násl. ISBN: 90-411-5425-6. 
na o kupní smlouvě z roku 1964. Díky této předloze je tedy izraelské právo ovlivněno také právem německým.

Právo izraelské považuje koupi za převod vlastnictví za přijetí určité protihodnoty, tedy ne nezbytně pouze finanční protiplnění. Kupní smlouvu je možné uzavř́it pro jakékoli vlastnické právo, a to včetně práva autorského. Vlastnické právo může stejně tak existovat $\mathrm{k}$ věci dosud neexistující a je tím pádem možné převádět i takové právo.

Izrael je smluvní zemí řady mezinárodních dohod v oblasti smluvního práva, jako je Úmluva o smlouvách o mezinárodní koupi zboží OSN (Organizace spojených národů) nebo Úmluva o uznání a výkonu cizích rozhodčích nálezů OSN. Členem obou těchto smluv je také Česká republika. Stejně tak v úvodu zmiňovaná asociační dohoda uzavřená mezi Státem Izrael a EU hraje roli i v oblasti obchodního práva vzhledem $\mathrm{k}$ tomu, že zakládá také dohodu o volném obchodu. Za zmínku stojí také dohoda o zamezení dvojího zdanění mezi Státem Izrael a Českou republikou.

Základním principem, od kterého se odvíjí charakter izraelského smluvního práva, je smluvní volnost. Tento princip představuje především fundamentální právo každého vstoupit do smluvního závazku a z konkrétnějšího hlediska zejména svobodu v otázkách znění takové smlouvy. Ani takové právo však není bez určitých omezení či limitů. Stěžejními hledisky pro posuzování neplatnosti smluvního ujednání jsou rozpor s veřejným zájmem, nedostatek dobré víry při sjednávání, případně také diskriminace slabší strany. V některých případech, a to zejména $\mathrm{v}$ oblasti nemovitostí, může být smluvní svoboda omezena normativními požadavky na formální úpravu takové smlouvy. V oblasti duševního vlastnictví však podobná omezení nepř́liš často nalézáme. Výjimku může tvořit povinnost smlouvy o převodu či poskytnutí práva duševního vlastnictví nechat zanést do příslušného rejstř́ku, aby byla taková smlouva účinná vůči třetím stranám. Po formální stránce však na taková ujednání nejsou kladeny žádné zvláštní zákonné požadavky.

V otázkách obecného omezení smluvní svobody zákon o smlouvách výslovně stanovuje absolutní podmínky neplatnosti tak, že pokud smlouva, její příprava, obsah nebo předmět mají nezákonnou povahu, případně jsou 
v rozporu s dobrými mravy či veřejným zájmem, je taková smlouva od počátku neplatnou. $\mathrm{V}$ případě, že je smlouva neplatnou, a přesto bylo $\mathrm{v}$ rámci jejích ustanovení plněno, je třeba učinit mezi stranami př́slušné narovnání. Taková situace je pochopitelně nepř́liš složitá u plnění hmotného, které je třeba druhé straně navrátit. Pokud se však jedná o plnění např́ílad v podobě služby, které není možné druhé straně předat zpět, vyžaduje zákon náhradu jiným způsobem v odpovídající hodnotě. Takovéto uvedení do původního stavu tedy nemusí nezbytně znamenat náhradu finanční. Pokud došlo k plnění jedné ze smluvních stran, je $\mathrm{v}$ takovém případě soud oprávněn druhé smluvní straně přes neplatnost smlouvy přikázat takové protiplnění vykonat. ${ }^{34}$ Nezákonná smlouva (případně smlouva, která je považována za neplatnou $\mathrm{z}$ důvodu rozporu $\mathrm{s}$ veřejným pořádkem nebo morálkou) tak není vždy od počátku neplatná a soud má možnost ponechat takovou smlouvu v platnosti, aby nedošlo k tomu, že by smluvní strana, která je odpovědná za nezákonnost smlouvy, získala jakýkoli prospěch, byṫ tím, že by dále nebyla povinna dle takové smlouvy plnit. ${ }^{35}$ Jedná se zde tak o prvek izraelského práva, který není obdobný ani právu anglickému či americkému ani právu českému (i s ohledem na absolutní důvody neplatnosti právního jednání). ${ }^{36}$

Princip dobré víry je, jak již bylo zmiňováno, po smluvní volnosti druhým nejdůležitějším principem izraelského smluvního práva. Zákona o smlouvách zde stanovuje povinnost jednat při vyjednávání smlouvy dle obchodních zvyklostí a v dobré viřre. Soudní praxe v Izraeli považuje princip

${ }^{34}$ Viz YOVEL, Jonathan; SHACHAM, Ido. Israeli Contract Law: An Overview. In KRITZER, Albert; EISELEN, Sieg; BUTLER, Allison; MAZZOTTA, Francesco. International Contract Manual, Volume 3. New York: Thomson Reuters, 2014. ISBN 9780314964366.

Soudce Menachem Elon v rozhodnutí níže citoval princip židovského práva „hříšník nikdy nemůže mít prospěch ze svého hříchu“, což je princip nápadně podobný ustanovení $§ 6$, odst.1 NOZ „Nikdo nesmí těžit ze svého nepoctivého nebo protiprávního činu. Nikdo nesmí těžit ani z protiprávního stavu, který vyvolal nebo nad kterým má kontrolu.“ Viz Rozhodnutí Nejvyššího soudu v Jeruzalémě 311/78 Miarah Nasim proti Howard Hania In: Nevo [online]. [cit. 27. 3. 2017] Dostupné z: www.nevo.co.il/Psika_word/elyon/PADI-LD-2-505L.doc.

${ }^{36}$ Viz FRIEDMANN, Daniel. Consequences of Illegality under the Israeli Contract Law (General Part) 1973. The International and Comparative Law Quarterly, ročník. 33, č. 1. Cambridge University Press, 1984. 
dobré víry za garanta smluvní volnosti a nikoli za její právní omezení. Princip dobré víry je tak aplikován jak na fázi vyjednávání o smlouvě, kde se jeví být nejpodstatnějším, tak také na samotný výkon smluvních ujednání. Současně je dobrá víra rozšířena i na oblast mimosmluvní, pokud věcně souvisí $\mathrm{s}$ výkonem dané smlouvy. Zde opět vidíme př́buznost smluvního práva a práva deliktního (tort). Stejně jako v př́ípadě občanského deliktního práva je i princip dobré víry vztahován nikoli pouze na samotné jednající strany, ale přeneseně či zástupně také na další osoby, které v průběhu vyjednávání smlouvy vystupují, at se již jedná o zástupce či k jednání jinak oprávněné osoby (například statutární orgán obchodní korporace).

Přímá zákonná podoba definice dobré víry se $\mathrm{v}$ izraelském právu nenachází a je tedy pouze dovozována soudní praxí dle již existujících rozhodnutí či řízení. Obecně je však považována spíše za objektivní kritérium ve způsobu jednání a nikoli nezbytně prvek ochrany před nepoctivým jednáním. Za nejtypičtější př́klady jednání s nedostatkem dobré víry jsou zamlčení podstatných informací, opuštění jednání v pokročilé fázi vyjednávání smlouvy či obdobné zmaření takového jednání. Nedostatek dobré víry zde však není uplatňován zcela automaticky. Vždy je třeba zkoumat konkrétní situaci, jelikož kupř́íladu opuštění jednání, byt̉ v pokročilé fázi vyjednávání smlouvy, může být snahou o zabránění vzniku budoucí škody, pokud by takové jednání pokračovalo a strana, která toto jednání opustila, má vážný důvod $\mathrm{k}$ takovému kroku. ${ }^{37}$

Naopak v okamžiku, kdy se strana účastní jednání v situaci, kdy si je vědoma, že nemá zájem toto jednání dokončit uzavřením takové smlouvy, nejedná v dobré viřre. $\mathrm{V}$ takové situaci, kdy strana jedná $\mathrm{s}$ nedostatkem dobré víry a odstoupí od uzavření smluvního závazku bez vážného důvodu, může soud rozhodnout tak, že se smlouva i přestože nebyla formálně uzavřena, považuje za platnou a účinnou, čímž zavazuje strany $\mathrm{k}$ plnění z předmětné smlouvy.

37 Viz YOVEL, Jonathan; SHACHAM, Ido. Israeli Contract Law: An Overview. In KRITZER, Albert; EISELEN, Sieg; BUTLER, Allison; MAZZOTTA, Francesco. International Contract Manual, Volume 3. New York: Thomson Reuters, 2014. ISBN 9780314964366. 
V právu českém se princip smluvní volnosti prosadil zejména nabytím účinnosti NOZ, který upouští od formalismů v duchu předchozí právní úpravy. Přesto se stále nejedná o úroveň smluvní svobody jako v případě práva izraelského, což vyplývá především z rozdílů mezi odlišnými druhy právních kultur, z nichž jmenované právní systémy vycházejí. Stejně jako v Izraeli se ale česká rekodifikace více zaměřila také na důraz dostatku dobré víry při vyjednávání smlouvy, když hovoří o povinnosti jednat v právním styku poctivě. Tato povinnost se samozřejmě vztahuje nejen na otázky smluvního práva, ale jedná se o obecnou povinnost i při jednání jiném. Je však třeba mít na paměti skutečnost, že izraelské právo nemá na rozdíl od Česka kodifikováno občanské právo, a proto se dle $\S 61$ vztahují ustanovení zákona o smlouvách i na všechna jednání nad rámec práva smluvního, pokud pro dané jednání neexistuje úprava zvláštní.

V případě vyjednávání smlouvy s nedostatkem dobré víry, náleží poškozené straně náhrada škody, kterou utrpěla tímto vyjednávání. Jedná se tedy o skutečnou škodu vzniklou přímým narušením vyjednávání. Soudní praxe však dále možnost náhrady škody rozšířila tak, že poškozená strana může nárokovat nejen škodu vzniklou, ale i škodu budoucí, která jí v důsledku takového vyjednávání hrozí. ${ }^{38}$ Může se jednat např́iklad o situaci, kdy vyjednáváním zmařený čas zpo̊sobí, že zahájení vyjednávání s další vhodnou stranou již nemusí být možné. Taková škoda v době jednání s nedostatkem dobré víry utrpěna nebyla, ale může hrozit až následně. Soud je tedy oprávněn i takovou škodu přiznat škůdci k náhradě. Obdobná situace existuje i v právu českém, kde soud může přiznat nejen skutečně vzniklou škodu, ale prríkladně také ušlý zisk, případně i přiměřené zadostiučinění, které se však obvykle vztahuje spíše k nemateriální škodě.

Není však možné přiznat náhradu vyšší, než je skutečná či potenciální škoda za účelem trestání škůdce. Zde se izraelské právo odlišuje od

\footnotetext{
38 Viz YOVEL, Jonathan; SHACHAM, Ido. Israeli Contract Law: An Overview. In KRITZER, Albert; EISELEN, Sieg; BUTLER, Allison; MAZZOTTA, Francesco. International Contract Manual, Volume 3. New York: Thomson Reuters, 2014. ISBN 9780314964366.
} 
podobného konceptu, který existuje $\mathrm{v}$ právu anglo-americkém, kde je možné rozšîrit náhradu škody soudem. ${ }^{39}$

Jak již bylo zmíněno, princip dobré víry se vztahuje také na výkon samotné smlouvy, a nejen na její vyjednávání. Zákon zde opět stanovuje povinnost uskutečnit smluvní plnění, což bylo vykládáno také jako náhrada přímé škody způsobené neuskutečněním výkonu daného smluvního ujednání. ${ }^{40}$ Soudní praxe i $\mathrm{v}$ tomto př́padě postupně zaujala stanovisko obecnější, kdy může být škůdce opět nucen nahradit škodu i nad rámec smluvního ujednání samého. Zde však není možné hovořit o pravidle, které by se dalo uplatnit univerzálně u všech smluv, jelikož různé okolnosti mohou být ve smlouvách řešeny odlišně včetně stanovení způsobů jejich nápravy a v takovém př́padě soud přihlíží pouze ke sjednanému nároku. ${ }^{41}$

V této souvislosti je jistě namístě poznamenat, že izraelské smluvní právo umožňuje také omezení rozsahu náhrady za škodu př́íkladně formou smluvní pokuty. Musí se však jednat o omezení, které je na straně druhé vyváženo určitým ekonomickým či jiným prospěchem omezené strany, který musí být přiměřený možné škodě. Jednostranné omezení odpovědnosti za škodu bez patřičného protiplnění by bylo v rozporu se zásadou rovnosti stran, respektive principem ochrany slabší strany a bylo by tak neplatné.

Otázka dobré víry dle izraelského práva však může být složitě vykládána v souvislosti s mezinárodním obchodem. Vzhledem $\mathrm{k}$ tomu, že v Úmluvě o smlouvách o mezinárodní koupi zboží OSN není ustanovení upravující dobrou víru zaneseno, liší se odborné názory na to, zda je i v takové smlouvě možné tento princip uplatňovat. Zde bude jistě hrát významnou roli svoboda volby práva, kterým se bude předmětná smlouva řídit. $V$ případě, že bude smlouva řízena právem izraelským nebo českým bude možné zásady

39 Viz BOHÁČEK, Martin, MACHŮ Matěj. Základy izraelského obchodního práva s dưrazem na ochranu duševního vlastnictví. Praha: Wolters Kluwer, 2016.

40 Viz SHALEV, Gabriela; HERMAN, Shael. A Source Study of Israel's Contract Codification. [online] Louisiana Law Review, číslo 35/1975. [cit. 29.5.2017] Dostupné z: http://digitalcommons.law.lsu.edu/cgi/viewcontent.cgi? article $=4117 \&$ context $=$ lalrev

${ }^{41}$ Viz ADAR, Yehuda. Legal Engineering in Israeli Law: Codification and Unification of the Law of Remedies. [online]. [cit. 29.5.2017] Dostupné z: http://weblaw.haifa.ac.il/he/Faculty/ Adar/Publications/LEGAL\%20ENGINEERING\%20IN\%20REMEDIES.pdf 
dobré víry i v takovém případě uplatňovat, jelikož oba právní systémy přistupují $\mathrm{k}$ této problematice obdobně.

\subsection{PRÁVO AUTORSKÉ}

Systém autorského práva ve Státě Izrael je v tomto článku představen pouze velmi obecně, aby poskytnul alespoň základní přehled hlavních aspektů moderního vývoje v této právní oblasti, a to s ohledem na větší důraz, který je zde kladen na problematiku práv průmyslového vlastnictví. ${ }^{42}$

Autorské právo je v izraelském pojetí charakteru především anglického. Do nedávné doby, tedy do roku 2007, byl v Izraeli stále účinným autorský zákon z roku 1911 společně s nařízením o autorském právu z roku 1924. Jak je patrné již z doby, kdy byly tyto předpisy vytvořeny, jedná se o předpisy anglické, což mělo i následně zásadní vliv při formování úpravy současné. $^{43}$ Pokud $\mathrm{k}$ této situaci připočteme, že v prvních desetiletích po vyhlášení samostatného státu hrálo i anglické právo soudní svou úlohu tím, že se k němu často izraelské soudy obracely, dalo by se předpokládat, že nedojde k zásadnímu odklonu od tohoto systému. ${ }^{44}$ Opak je však pravdou, vzhledem k tomu, že nový autorský zákon z roku $2007^{45}$ anglickou předlohu opouští a hledá inspiraci především za oceánem, at již ve Spojených státech nebo na Novém Zélandu, ba i v Singapuru. Izraelské právo zde tedy opět potvrzuje svůj charakter smíšeného právního systému inkorporací americké doktríny fair use s velkým do̊razem na osobnostní práva autora, což je v porovnání s jinými systémy poněkud nezvyklá kombinace.

${ }^{42}$ Podrobněji se problematice autorského práva ve Státě Izrael věnuje monografie BOHÁČEK, Martin, MACHŮ Matěj. Základy izraelského obchodního práva s dưrazem na ochranu duševního vlastnictví. Praha: Wolters Kluwer, 2016. ISBN 978-80-7552-038-8.

${ }^{43}$ Podrobněji o historickém vývoji autorského práva na území státu Izrael s přihlédnutím k vlivu anglického, osmanského i židovského práva pojednává BIRNHACK, Michael D. Colonial copyright: intellectual property in mandate Palestine. First edition. Oxford: Oxford University Press, 2012. ISBN 01-996-6113-8.

${ }^{44}$ Z vyjádření Attorney General lze usuzovat, že veškerá judikatura, která není v přímém rozporu $s$ ustanoveními nového autorského zákona je nadále aplikovatelná, přestože vznikla v době účinnosti předchozí právní úpravy. Viz LISS, Eran a ADIN, Dan. Intellectual property law and practice in Israel. New York: Oxford University Press, 2012. s. 352 ISBN: 978019-9917-419.

45 Viz autorský zákon z roku 2007 In: Nevo. [online]. [cit. 27. 3. 2017] Dostupné z: https://www.nevo.co.il/law_html/Law01/999_853.htm 
V každém případě v Izraeli stále hovoříme o systému copyright a nikoli droit d'auter ${ }^{46}$, z čehož logicky vyplývá také princip převoditelnosti majetkových práv autora. Zatímco nepřevoditelnými zůstávají pouze práva osobnostní. ${ }^{47}$ Odklon od anglického přistupu $\mathrm{k}$ tzv. volnému užití díla $\mathrm{v}$ podobě fair dealings $\mathrm{k}$ americkému modelu fair use, byl dlouho očekávanou změnou, která podstatným způsobem rozšírila okruh takového užití. Původní předpisy zde stanovovaly taxativní výčet užití, které je vlastník autorských práv majetkových povinen strpět a při nichž nedochází $\mathrm{k}$ nezákonnému zásahu do těchto práv. Současný systém odstranil výčet a nahradil jej fair use testem, tedy obecněji definovanými podmínkami, při jejichž kumulativním naplnění se o volné užití jedná, či přesněji, pokud se osoba užívající předmět autorského práva pohybuje $\mathrm{v}$ limitech daných autorským zákonem.

Tento přístup sebou však přináší určitá úskalí, která byla nejpatrnější v počátcích jeho uplatňování, a to poměrně široká možnost výkladu jednotlivých částí fair use testu. Zde tedy bylo nutné vytvořit určité mantinely prostřednictvím soudní praxe, podobně jako ve Spojených státech. V konečném důsledku se ale především s ohledem na rychlý vývoj moderních technologií ukazuje otevřenější a pružnější fair use vhodnějším než poněkud rigidní systém fair dealings.

Anglo-americký model copyright také tradičně vylučuje souběh ochrany autorskoprávní a průmyslově-právní (s výjimkou ochranných známek či obecněji práv na označení). $V$ případě, kdy je určité dílo (zpravidla hovoříme o dílech užitého umění) předmětem ochrany zápisem průmyslového vzoru, není možné uplatnit ochranu autorskoprávní ve vztahu k témuž dílu. Tento princip však nekončí u tohoto modelu ve fázi takř́kajíc „bud’ anebo“, ale obecněji, pokud je dané dílo způsobilé ochrany jakožto průmyslový

\footnotetext{
${ }^{46}$ Anglický v. francouzský model autorského práva.

${ }^{47}$ Zde je namístě připomenout důraz na smluvní svobodu, která je klíčovým prvkem izraelského práva. Osobností práva autora, pokud není ujednáno jinak, mají silnou pozici i vůči uplatnění doktríny fair use, která je po americkém vzoru relativně široká. Na druhou stranu, pokud jinak ujednáno je, nevylučuje izraelské právo i určité omezení uplatnění osobnostních práv autorem, za podmínky, že by takové ujednání nebylo vůči autorovi nespravedlivým.
} 
vzor $^{48}$, je nezbytné, aby si jeho vlastník průmyslově-právní ochranu zabezpečil, protože at již k zápisu do rejstř́ku dojde či nikoli (nebo bez ohledu, zda ochranu vlastník žádá), není takové dílo předmětem ochrany dle autorského práva.

Za zmínku zde stojí také podmínky ochrany, za kterých je autorskoprávní ochrana dílům přiznávána, kde izraelská soudní praxe dovodila dílčí aspekty podmínky původnosti ${ }^{49}$. Jsou jimi tzv. tvořivost a vlastní tvorba. Vlastní tvorbu chápeme jako odlišnost díla od děl starších, tedy se jedná o jistou formu novosti, zatímco pojem tvořivosti vyžaduje, aby bylo dílo výsledkem duševního úsilí jeho autora. ${ }^{50,51}$

Velmi důležitým rozdílem vưči běžnému českému pojetí je institut díla zaměstnaneckého. V českém prostředí je dílo považováno za zaměstnanecké, tedy dílo, jehož práva náleží zaměstnavateli, pokud $\mathrm{k}$ jeho vytvoření došlo $\mathrm{v}$ průběhu plnění povinností plynoucích z pracovněprávního nebo služebního vztahu. V Izraeli je ovšem situace o poznání komplikovanější vzhledem $\mathrm{k}$ tomu, že zaměstnaneckým dílem je dílo vytvořené $\mathrm{v}$ rámci plnění pracovního úkolu zaměstnancem. $\mathrm{Z}$ této definice pochopitelně není rozdíl patrný, odlišně totiž přistupuje izraelské právo $\mathrm{k}$ pojmu zaměstnance. $\mathrm{V}$ oblasti autorského práva se nevykládá pojem zaměstnání dle práva pracovního. Je zde namístě zkoumat skutečný stav, $\mathrm{v}$ jakém byl pracovní úkol plněn. Judikatura na tomto místě zdůrazňuje především prvek dohledu zaměstnavatele (objednatele) ${ }^{52} \mathrm{~V}$ př́ípadě, že zaměstnavatel

${ }^{48}$ Srov. Rozhodnutí Oblastního soudu v Tel Avivu 1253/05 H.Stern Comerció e Industria S.A. et al., proti A. Arnil Ltd et al. In: Nevo [online]. [cit. 27. 3. 2017] Dostupné z: https://www.nevo.co.il/psika_html/mechozi/ME-05-1253-583.htm

49 Viz Rozhodnutí Nejvyššího soudu v Jeruzalémě 513/89 Interlego S.A. proti Exin Lines Bros. S.A., et al. In: Nevo [online]. [cit. 27. 3. 2017] Dostupné z: www.nevo.co.il/ Psika_word/elyon/PADI-NG-4-133-L.doc

${ }^{50}$ Pokud pro srovnání nahlédneme do české definice autorského díla, nacházíme zde podmínku velmi podobnou, kdy dílo musí být výsledkem tvưrčí činnosti autora. Důraz je tedy $\mathrm{v}$ obou případech kladen na osobní projev autora a jeho individualitu při tvorbě díla.

51 Viz Rozhodnutí Nejvyššího soudu v Jeruzalémě 8485/08 FA Premier League et al. proti the Israeli Sporting Gambling Association In: Nejvy̌ší soud v Jeruzalémě [online]. [cit. 27. 3. 2017] Dostupné z: http://elyon1.court.gov.il/files/08/850/084/h02/08084850.h02.pdf

${ }^{52}$ Viz Rozhodnutí Nejvyššího soudu v Jeruzalémě 571/68 David Yanai proti El Mansfeld In: Nevo [online]. [cit. 27. 3. 2017] Dostupné z: https://www.nevo.co.il/ psika_html/elyon/e23-68000571.pdf 
dohlíží na práci zaměstnance, byt by pracovní úkol prováděl například na základě smlouvy o dílo, připadají majetková práva $\mathrm{k}$ dílu zaměstnavateli (objednateli), pokud není ujednáno jinak. Tento př́stup je dále uplatňován $\mathrm{v}$ př́ípadě práv $\mathrm{k}$ průmyslovému vlastnictví, jak je uvedeno níže.

\subsection{PRÁVNÍ OCHRANA PRŮMYSLOVÉHO VLASTNICTVÍ}

Úvodem zmiňme, že základním stavebním kamenem pro ochranu průmyslových práv jsou mezinárodní smlouvy. Základní principy práv k průmyslovému vlastnictví sahají již do předminulého století, kdy vstoupila $\mathrm{v}$ platnost Pařížská unijní úmluva. Tato úmluva měla sjednocující charakter a ustanovila pravidla, která jsou v průmyslově-právním oboru platná dodnes.

Jedním ze zásadních prvků této úmluvy byla definice, která přesně vymezila předmět ochrany průmyslového vlastnictví. Úmluva rovněž harmonizovala řízení vedoucí $\mathrm{k}$ nabytí ochrany na předmět průmyslového vlastnictví. V roce 1883 stály u podpisu smlouvy následující státy: Belgie, Brazílie, Španělsko, Francie, Guatemala, Itálie, Nizozemsko, Portugalsko, Salvador, Srbsko a Švýcarsko. Tehdejší Československo přistoupilo roku 1919 a Izrael roku $1949 .{ }^{53}$ Dodržování principů stanovených v této úmluvě je pro členské státy závazné. Členské země jsou také na základě Pařǐžské unijní úmluvy povinny zř́ídit zvláštní úřad spravující průmyslově-právní agendu a při řízení zacházet se zahraničními přihlašovateli stejně jako s domácími zájemci o ochranu ${ }^{54}$.

Zřízení prvního československého Patentního úřadu se datuje do roku 1919. Po rozdělení Československa vznikl samostatný Úřad průmyslového vlastnictví (ÚPV), který dnes sídlí v pražském Bubenči. Izraelský patentový úřad (Reshut Hapatentim, dále IPÚ), sídlící v Jeruzalémě, byl zřízen rovněž

53 Současný počet 176 států. Viz WIPO. Aktuální přehled přistoupivších států - Pařǐžská úmluva. [online]. Dostupné z: http://www.wipo.int/treaties/en/ShowResults.jsp?treaty_id=2

${ }^{54} \mathrm{~K}$ dalším pravidlům, které s sebou tato úmluva přinesla, patří: nezávislost udělených právních ochran, právo na patent a na uvedení jména původce vynálezu, odepření nebo zrušení patentu z důvodu nedovoleného prodeje, nucené licence a předepsané užívání vynálezu, poshověcí lhůta k zaplacení udržovacích poplatků, principy výlučné ochrany předmětů průmyslového vlastnictví, formy právní ochrany průmyslového vlastnictví (například také ustanovení dodatkových ochranných osvědčení, ochrany nových rostlinných odrůd či ochrany obchodního jména) 
jako český úřad v období po 1 . světové válce. IPÚ není na rozdíl od ÚPV úřadem samostatným či ústředním, jelikož se zde jedná o organizační jednotku v rámci ministerstva spravedlnosti. Jako oddělení patentů spadající pod ministerstvo fungoval patentový úřad již v období britského mandátu v Palestině a první přihláška vynálezu zde byla podána v roce 1917. V současné podobě funguje patentový úřad od roku 1959. Úředním jazykem v Izraeli je již od roku 1948 pouze hebrejština a částečně doposud i arabština. Do roku 1948 byla úředním jazykem rovněž angličtina, která dodnes zastává na území Izraele důležitou roli. Zejména pak v oblasti ochrany průmyslového vlastnictví, protože IPÚ přijímá přihlášky na udělení ochrany kromě hebrejštiny a arabštiny i v anglickém jazyce. Přihlašovatel si může pro podání přihlášky zvolit jeden $\mathrm{z}$ výše uvedených jazyků, ve kterém uvede popis vynálezu a patentové nároky, ale nesmí však opomenout uvést název vynálezu v hebrejštině $\mathrm{i}$ angličtině. ${ }^{55}$ Izrael se řadí $\mathrm{k}$ zemím s rozvinutou ochranou průmyslového vlastnictví a je členem všech dalších významných mezinárodních smluv, tj. Bernské úmluvy, Úmluvy o zřízení Světové organizace duševního vlastnictví, Madridské úmluvy, Lisabonské úmluvy, Budapeštské smlouvy o mezinárodním uznávání uložení mikroorganismů a Úmluvy na ochranu nových rostlinných odrůd.

\section{OCHRANA TECHNICKÝCH ŘEŠENÍ}

Technická řešení lze v Izraeli chránit pouze pomocí jediného ochranného institutu, jímž je patent. Oproti tomu v České republice mají přihlašovatelé možnost zvolit si mezi dvěma možnými ochrannými instituty pro ochranu svého technického řešení, jímž je kromě patentu i užitný vzor. V českém právním systému je ochrana užitným považována vzorem za velmi mladou, jelikož byla přijata až po roce 1989. Právo na ochranu užitným vzorem má v České republice původce, příp. jeho právní nástupce, anebo podnikatelský subjekt, který $\mathrm{v}$ rámci své činnosti přinese nějakou inovaci s podstatou technického řešení, tj. vytvoří užitný vzor jako fyzický výrobek nebo

\footnotetext{
${ }^{55}$ Srov. BOHÁČEK, Martin, MACHŮ Matěj. Základy izraelského obchodního práva s dưrazem na ochranu duševního vlastnictví. Praha: Wolters Kluwer, 2016. s. 76-77 ISBN 978-80-7552-0388.
} 
model. Užitným vzorem v ČR nemůže být technický postup. ÚPV vede rejstř́k užitných vzorů, do něhož se v rámci průzkumu zápisuschopnosti přihlašovaného řešení užitné vzory zapíší. Tento průzkum, resp. řízení je oproti průzkumu zápisuschopnosti vynálezů zjednodušený.

Přihlašovatel užitného vzoru podává u ÚPV vyplněný formulář s uvedeným popisem a nároky na ochranu. Řízení provede ÚPV zpravidla během 6 měsíců od podání přihlášky na základě průzkumu formálních požadavků a zjistí, zda se nejedná o řešení vyloučené $\mathrm{z}$ ochrany zákonem, tj. prověří základní zápisné podmínky. Přihlašované technické řešení se neporovnává se stávajícím stavem techniky, a zároveň se nezkoumá vynálezecká úroveň. Je tedy nasnadě, že může být zapsáno i takové řešení, které je ve své podstatě triviální a nesplňuje podmínky novosti a nepřesahuje rámec pouhé odborné dovednosti. Zkoumání podmínek pro zápis do rejstř́ku probíhá až ve fázi výmazového řízení, pokud někdo již zapsaný užitný vzor napadne. ${ }^{56}$

Pro přiblížení pozadí užitného vzoru jako ochranného institutu průmyslového vlastnictví je nezbytné zmínit, že původní právní úprava pochází z Německa, kde se rozvíjela již od roku 1891 a v českém právu se z této předlohy vycházelo, $\mathrm{z}$ komplexního pohledu nejen $\mathrm{v}$ souvislosti $\mathrm{s}$ tvorbou právní úpravy pro ochranu technických řešení užitným vzorem. V současnosti platný zákon č. 527/1990 Sb., o vynálezech, průmyslových vzorech a zlepšovacích návrzích byl tehdy doplněn zákonem č. 478/1992 Sb., který nabídl i jiný způsob ochrany než jen patentem. Hlavním aspektem pro přípravu samostatného zákona právní ochrany užitných vzorů byl tehdy přechod k tržní ekonomice.

Ve srovnání s Českou republikou Izrael při tvorbě právních úprav nikdy nečerpala a nevycházela přímo $\mathrm{z}$ německého systému. Této oblasti byla Izrael v minulosti ve své podstatě velmi vzdálená, protože historicky izraelské patentové právo vychází $\mathrm{z}$ anglického vzoru s pozdějším vlivem práva amerického. Jakožto právní systém spadající z velké části do oblasti angloamerické právní kultury se zde proto nesetkáváme s institutem užitného

${ }^{56}$ Srov. JAKL, Ladislav. Metodologie vědy a výzkumu se zaměrením na oblast práv $k$ průmyslovému a jinému duševnímu vlastnictví. Praha: Metropolitan University Prague Press, 2015. s. 42-44 ISBN: 978-80-87956-24-3. 
vzoru, výjimku v této právní kultuře představuje Austrálie, která zavedla ochranu tzv. inovačním patentem. V současnosti však lze v Izraeli pozorovat nový vliv prostřednictvím jednostranné pokračující harmonizace $\mathrm{s}$ Evropským patentovým úřadem (EPO), a proto můžeme v budoucnu očekávat snahu o připojení k Úmluvě o udělování evropských patentů (EPÚ).

\subsection{OCHRANA VYNÁLEZŮ PATENTEM}

V současnosti je izraelskou platnou právní úpravou na ochranu technických řešení patentový zákon z roku $1967^{57}$, který byl později několikrát novelizován. Tento zákon navázal na původní předpis o patentech a designech z roku 1924. Současný patentový zákon reflektuje taktéž harmonizační prvky spojené $s$ př́stupem $\mathrm{k}$ Dohodě o patentové spolupráci (Patent Cooperation Treaty - PCT) v roce 1996, ke které se připojily téměř všechny státy s existující ochranou průmyslového vlastnictví. ${ }^{58}$

Jak již bylo předesláno na úvod, spravuje agendu související s udělením ochrany patentem IPÚ, který zastává rovněž funkci archívu průmyslověprávních informací a mezinárodního rešeršního úřadu (International Searching Authority - ISA). Obdobně jako český úřad shromažduje IPÚ informace týkající se jednotlivých ochranných institutů v elektronických databázích dostupných na internetu, ale uchovává i fyzické dokumenty v papírové podobě..$^{59}$

V Izraeli se udělují výlučná práva na ochranu technických řešení patentem dle již výše zmíněného patentového zákona, který však nedefinuje přesně pojem vynálezu, ale stanovuje podmínky, za kterých je řešení patentovatelné. Je nezbytné, aby vynález splňoval 4 následující podmínky: světová novost, užitečnost, průmyslová využitelnost, řešení jako výsledek vynálezecké činnosti obnášející vynálezecký krok.

\footnotetext{
${ }^{57}$ Viz Patentový zákon z roku 1967. In: Nevo. [online]. [cit. 27. 3. 2017] Dostupné z: https://www.nevo.co.il/law_html/Law01/P187_002.htm

${ }^{58}$ Současný počet 151 států. Viz WIPO. Aktuální seznam přistoupivších států - PCT. [online]. Dostupné z: http://www.wipo.int/pct/en/pct_contracting_states.html

${ }^{59}$ Odkaz pro vstup do databází dle jednotlivých ochranných institutů na stránkách IPÚ. [online]. [cit. 27. 3. 2017] Dostupné z: http://www.justice.gov.il/En/Units/ILPO/ About/Pages/default.aspx
} 


\subsection{PODMÍNKA NOVOSTI}

Při posuzování novosti vynálezu nehovoří izraelské právo o institutu stavu techniky, nýbrž uvádí, co je na závadu novosti. Pro vysvětlení uved’me, že pokud by někdo žádal o patent pro tentýž vynález jako někdo před ním, bude jeho přihláška zamítnuta ne pro nedostatek novosti, ale dle $\S 9$, tedy ve smyslu, že přihlašovatel není první. Extrémní situací by mohl být případ, kdy je vynález objasněn ve starší nezveřejněné přihlášce, avšak není nárokován, což není na závadu novosti (dle §4) ani na závadu toho, že by přihlašovatel nebyl první (dle $\S 9$ ), protože by nedošlo $\mathrm{k}$ udělení dvou patentů na tentýž vynález. Takový postup se částečně ${ }^{60}$ odlišuje od českého i evropského systému. Dle izraelské právní úpravy se tedy ve sporné situaci přihlédne k ustanovení $\S 9$ patentového zákona, které prriznává právo př̀ednosti $^{61}$. K výčtu možného zpř́istupnění veřejnosti se řadí následující skutečnosti: zveřejnění popisu vynálezu v písemné, obrazové, hlasové nebo jiné podobě nebo užití či vystavení vynálezu takovým způsobem, že by osoba oboru znalá dovedla totožný vynález uskutečnit.

Obdobně jako ve většině zemí existuje v Izraeli 6 měsíční poshověcí lhůta neboli grace period, která umožňuje přihlašované řešení ochránit před neuznáním, tj. nesplněním podmínky novosti vynálezu vzhledem ke světovému stavu techniky $\mathrm{v}$ př́ípadě, že dojde $\mathrm{k}$ předuveřejnění vynálezu samotným vynálezcem na úředně uznané výstavě, která trvá alespoň 3 týdny. Taktéž je aplikovatelná poshověcí lhůta $v$ případě, že ke zveřejnění došlo zřejmým zneužitím vůči přihlašovateli. $V$ souvislosti zřejmého zneužití vynálezu však izraelská právní úprava nestanovuje konkrétní lhůtu pro po-

${ }^{60}$ Srov. § 4, odst 2 zák. č. 478/1992 Sb., o užitných vzorech. In: Portál veřejné správy. [online]. [cit. 27. 3. 2017] Dostupné z: https://portal.gov.cz/app/zakony/zakonPar.jsp?idBiblio $=40246 \& \mathrm{nr}=478 \sim 2 \mathrm{~F} 1992 \& \mathrm{rpp}=15 \#$ local-content

${ }^{61}$ Pro přihlašovatele byla zavedena prioritní lhůta dle Pařǐžské unijní úmluvy. Užívá se též termínu priorita a vzniká přihlašovateli podáním patentové přihlášky. Uplatňuje-li přihlašovatel právo přednosti z již dříve podané přihlášky podle zmiňované mezinárodní smlouvy, musí v žádosti uvést datum podání přihlášky, z níž právo přednosti odvozuje, její číslo, stát, $\mathrm{v}$ němž byla přihláška podána, popřípadě orgán, u něhož byla přihláška podána. Na výzvu úřadu ve lhůtě jím stanovené je přihlašovatel povinen vnik práva přednosti doložit. 
dání přihlášky, ale hovoří jen o tzv. přiměřené lhůotě poté, jež se o zneužití neboli publikaci bez vědomého souhlasu dozvěděl. ${ }^{62}$

\subsection{VYNÁLEZECKÝ KROK}

Pojmem vynálezecký krok (dle hebrejského znění vynálezecký pokrok) se rozumí míra tzv. nezřejmosti přihlašovaného vynálezu, který v rámci posuzovaní splnění této podmínky musí projevit dostatečnou inventivnost. Znalec daného oboru, přesněji řečeno fiktivní osoba, zkoumá, zda je vynález pro něj zjevný anebo se vymezuje vůči již existujícímu stavu techniky svým vynálezeckým krokem, který je nezbytný pro získání takového řešení. Nutno podotknout, že tento aspekt se posuzuje velmi složitě a při průzkumu může dojít k rozdílným závěrům.

V souvislosti s chybějící přesně danou a ustálenou definicí znaku „zřejmý - zjevný“, nejen v Izraeli či České republice, ale i napříč státy, dochází rovněž při rozhodovací praxi sporných př́ípadů $\mathrm{k}$ nejednotnému výkladu. Logicky toto vede $\mathrm{k}$ prohloubení pochyb, co vlastně samotná zřejmost představuje, a jak ji interpretovat veřejnosti i možným zájemcům o ochranu.

\subsection{UŽITEČNOST A PRŮMYSLOVÁ VYUŽITELNOST VYNÁLEZU}

Oproti evropskému právu, Izrael vyžaduje užitečnost vynálezu, kterou přihlašovatel ztvrzuje př́islibem, že přihlašovaný vynález využitelný pro dosažení určitého efektu. Tato podmínka je však chápana spíše jako formální než věcná ${ }^{63}$ a Izrael ji přejala $\mathrm{z}$ práva amerického, na jehož základech také vytvářela svou právní úpravu.

Přihlašovaný vynález musí disponovat průmyslovou využitelností, tj. být přínosným pro svůj technologický obor v rámci své opakovatelné realizace. ${ }^{64}$ Pojem technologický obor se užívá v souvislosti s implementací nových prvků dohody TRIPS. Pojem však stále ve své podstatě potvrzuje

${ }^{62}$ Blíže viz BOHÁČEK, Martin, MACHŮ Matěj. Základy izraelského obchodního práva s dưrazem na ochranu duševního vlastnictví. Praha: Wolters Kluwer, 2016. s. 79 ISBN: 978-80-7552038-8.

${ }^{63}$ Užitečnost vynálezu spočívá především v jeho schopnosti řešit určitý problém.

${ }^{64}$ Pojem průmyslové využitelnosti se váže na samotnou věcnou proveditelnost vynálezu., kdy daný vynález např́iklad nesmí odporovat fyzikálním zákonitostem. 
fakt, že je zapotřebí alespoň prokazatelná možnost, že by byl vynález v současnosti či budoucnosti vyrobitelný a využitelný $\mathrm{v}$ průmyslu, zemědělství nebo v jiných oblastech hospodářství. Z tohoto faktu „pouhé možnosti“ vyplývá, že není při podání přihlášky nutná garance, že skutečně vynález zaujme pevné místo na trhu a bude předmětem obchodních vztahů.

\subsection{DOBA OCHRANY PATENTEM A PRŮBĚH ŘÍZENÍ}

Patent na vynález poskytuje přihlašovateli v Izraeli právní ochranu po dobu 20 let od podání přihlášky, již je oprávněn podat vlastník vynálezu. Vlastníkem vynálezu je ta osoba, která vynález sama vynalezla či její právní nástupce, který nabyl práva převodem či přechodem vlastnictví. Patent zpravidla nabývá účinku až po zápisu o udělení do Věstníku, který IPÚ pravidelně s aktuálními informacemi vydává. Doba účinku patentu proto nečiní 20 let, ale je zkrácena poměrně o dobu udělovacího řízení. Přihlašovatelé získávají ochranu uděleným patentem zhruba 3 až 6 let od data podaní přihlášky.

Dle mezinárodně harmonizovaných lhůt zveřejní Izraelský patentový úrad přihlášku po uplynutí 18 měsíců od data priority. Prvotní fáze zkoumání se nazývá Předběžný průzkum patentové přihlášky a úřad může i $\mathrm{v}$ této fázi řízení shledat, že přihláška obsahuje předmět vyloučený z patentování a zamítnout ji, čímž by nedošlo $\mathrm{k}$ jejímu zveřejnění.

Nejpozději do 36 měsíců od podání přihlášky dochází k následující významné procesní fázi, o kterou musí přihlašovatel sám zažádat. Nazývá se Úplný průzkum patentovatelnosti. Ǩízení o přihlášce tímto končí a výsledkem jsou trri následující možnosti: zamítnutí přihlášky, zastavení řizení o přihlášce anebo udělení patentu a zveřejnění patentového spisu. Aby byla ochrana udělených patentů jednoznačně vymezena, jsou v rámci přihlášky stanoveny patentové nároky. Ke správnému vyložení pojmů z nárokovaného rozsahu ochrany slouží i popis vynálezu, př́padně i výkresy.

Majitel, jemuž je udělen patent, disponuje výlučným právem, které se v praxi vyznačuje právem vynález využívat, poskytnout licenci třetím osobám nebo vynález převést. Vynález lze využívat př́imo či nepřímo. Mezi přímé využívání spadá: vyrábění, nabízení, uvádění na trh nebo pou- 
žívání výrobku, který je předmětem patentu, nebo $\mathrm{k}$ tomuto účelu výrobek dovážet či skladovat, anebo s ním jiným způsobem nakládat. Oproti tomu nepřímé využívání je definováno následovně: bez souhlasu majitele patentu není dovoleno dodávat nebo $\mathrm{k}$ dodání nabízet jiné osobě než je osoba oprávněná prostředky týkající se podstatného prvku chráněného vynálezu a sloužící k jeho uskutečnění. Majitel patentu je povinen platit udržovací poplatky, které zajistí ochranu na nejvýše možnou dobu ochrany 20 let. Oproti českému systému placení udržovacích poplatků, platí v Izraeli model, kdy je první poplatek nutné uhradit do 3 měsíců od udělení ochrany a další po uplynutí 6., 10., 14. a 18. roku trvání ochrany. ${ }^{65}$

Majitel patentu má možnost požádat o prodloužení doby ochrany zejména jen na farmaka, a to $\mathrm{v}$ souvislosti $\mathrm{s}$ časově nákladným povolením uvést přípravek na trh dané země. Dodatečné prodloužení ochrany se poskytuje v rámci prodlužovacího př́kazu. Oproti České republice, kde se v takových př́padech uděluje př́́davkový patent až na dobu 5 let, se v Izraeli nevydává zvláštní dokument, který poskytuje ochranu nad rámec dvaceti let, ale je prodloužena doba ochrany samotného patentu na základě výše zmíněného př́kazu. Podobně jako v USA lze výpočet pro prodlužovací prríkaz nalézt v patentovém zákoně, konkrétně v § 64a a násl.

Účinky patentu mohou být ovšem omezeny. Omezení nastává v př́ípadě zjištění existence předchozího uživatele, který využíval tentýž vynález nezávisle na majiteli patentu. Patentový zákon rovněž hovoří o nucené licenci, ke které může dojít $\mathrm{v}$ případě nedostatečného využívání vynálezu a mohla by být vynucena státními orgány $\mathrm{v}$ zájmu veřejnosti, nejčastěji v souvislosti ohrožení obyvatelstva při nedostatku vyrobených léčiv apod. Činnost, která je prováděna pro neobchodní účely, např́klad neziskovou organizací, anebo činnost, která je prováděna na experimentální úrovni na akademické půdě, bude též řazena k omezeným účinkům patentu.

Patent zaniká třemi způsoby. První možností je uplynutí dvacetileté doby ochrany, druhou je zánik zapříčiněný nezaplacením ročních udržova-

\footnotetext{
${ }^{65}$ Blíže viz aktuální informace o poplatcích na stránkách IPÚ [online]. Dostupné z: https://ecom.gov.il/Counter/general/homepage.aspx?counter $=14 \&$ catalog $=2 \&$ category $=$ patents\&language $=\mathrm{e}$
} 
cích poplatkư $^{66}$ a třetí, pokud sám majitel učiní rozhodnutí vzdát se patentu. Zánik patentu nastává od doby, kdy tato skutečnost nastane. $V$ případě zrušení je patent zrušen zcela nebo jen částečně. Ke zrušení patentu dochází, pokud nebyly splněny zákonem stanovené podmínky $\mathrm{k}$ jeho udělení, např́íklad popis nebyl dostatečně jasný, byl udělen nad rámec původního podání přihlášky, či udělen osobě, jež nebyla oprávněna patent nabýt (spory zpravidla řešeny soudy při tzv. určovacím ř́zení). Ve srovnání se zánikem patentu platí zrušení již od samého počátku jeho platnosti.

\subsection{ZAMĚSTNANECKÉ VYNÁLEZY}

Zaměstnanecké vynálezy vytvořené $\mathrm{v}$ rámci pracovního poměru či obecně $\mathrm{i}$ pracovního úkolu jsou zahrnuty do izraelského patentového zákona jako vynálezy náležející zaměstnavateli. Na rozdíl oproti českému systému, který odkazuje pouze na pracovní poměr primárně dle zákoníku práce ${ }^{67,68}$. V Izraeli tedy např. vynález vytvořený v rámci smlouvy o dílo může být "podnikovým vynálezem" a práva nemusí být převedena na základě zvláštního smluvního ujednání. Obecně lze říct, že v Izraeli nezáleží na právním typu provádění práce, ale na jejím věcném charakteru.

Zaměstnavatel musí být neprodleně informován o skutečnosti, že takový vynález vznikl. Vlastníkem vynálezu je dle patentového zákona zaměstnavatel, který se však musí do 6 měsíců od obdržení vyrozumění o vzniku vynálezu vyjádřit, zda svá vlastnická práva k vynálezu přijímá. Pokud by na vyrozumění nereagoval, přechází vlastnická práva od počát-

${ }^{66} \mathrm{~V}$ takovém prrípadě lze však využít šestiměsíční poshověcí lhůtu pro obnovení patentu.

${ }^{67}$ Pracovní poměr je zde definován jako pracovní poměr, členský nebo jiný obdobný pracovněprávní vztah. Viz $\S 9$, odst. 1 zák. č. 527/1990 Sb., o vynálezech a zlepšovacích návrzích. In: Portál veřejné správy. [online]. [cit. 27. 3. 2017] Dostupné z: https://portal.gov.cz/app/zakony/zakonPar.jsp?idBiblio = 38896\&nr $=527 \sim 2 F 1990 \& r p p$ $=15 \#$ local-content

${ }^{68}$ Srov. Autorský zákon stanovuje $\mathrm{v}$ př́padě zaměstnaneckého díla podmínky přesněji než zákon o vynálezech, když hovoří o pracovněprávním či služebním vztahu k zaměstnavateli nebo pracovním vztahem mezi družstvem a jeho členem. Viz § 58, odst. 1 zák č. 121/2000 Sb., o právu autorském, o právech souvisejících s právem autorským a o změně některých zákonů. In: Portál veřejné správy. [online]. [cit. 27. 3. 2017] Dostupné z: https://portal.gov.cz/app/zakony/zakonPar.jsp?idBiblio $=49278 \&$ fulltext $=$ autorsk $\sim$ C3 $\sim$ $\mathrm{BD} \sim 20 \mathrm{z} \sim \mathrm{C} 3 \sim \mathrm{A} 1 \mathrm{kon} \& \mathrm{rpp}=15 \#$ local-content 
ku vzniku vynálezu na zaměstnance. V minulosti byly v Izraeli zaměstnanecké vynálezy předmětem sporů a jedním ze zásadních rozhodnutí bylo, že vynález musí být v době trvání zaměstnaneckého poměru skutečně vytvořen, nejen pouze vymyšlen. ${ }^{69}$

\subsection{VÝLUKY Z PATENTOVATELNOSTI}

Na základě izraelského patentového zákona nelze patentovat samostatné objevy, vědecké teorie, terapeutické metody péče o lidské tělo, matematické metody, nové druhy rostlin ${ }^{70}$ a zvířat s výjimkou mikroorganismů, plány, pravidla a zpo̊soby vykonávání duševní činnosti a počítačové programy. Ochrana patentem by nebyla udělena ani přihlašovateli, jehož vynález by byl v rozporu s obecnými zájmy, tj. se zásadami lidskosti a veřejné morálky, i přestože toto ustanovení již není explicitně začleněno do patentového zákona, vychází však ze zásad smluvního práva. ${ }^{71}$

V současnosti je celosvětově diskutována otázka ochrany počítačových programů. $^{72} \mathrm{~V}$ Evropě převládá trend, že počítačové programy jako takové $^{73}$ patentovatelné nejsou, ale lze je chránit dle autorského zákona. Taková ochrana se však vztahuje pouze na vizuální podobu programu, tj. kódovací prvky, nikoliv na samotnou myšlenku a funkci programu. Na evropské podmínky patentovatelnosti počítačových programů lze nahlížet jako na přísnější než je tomu např. v USA. Po vzoru americké patentové právní úpravy, která ochranu počítačových programů jako patentovatelný vynález

${ }^{69}$ Viz Řízení před Oblastním soudem v Tel Avivu 729/80 Moshe Dolev proti Abraham Amgar In: University of Haifa [online]. [cit. 27. 3. 2017] Dostupné z: http://moodle.haifa.ac.il/ $\bmod /$ resource/view.php?id $=28702 \&$ redirect $=1$.

${ }^{70}$ Nikoli rostliny samotné.

${ }^{71}$ Srov. BOHÁČEK, Martin, MACHŮ Matěj. Základy izraelského obchodního práva s dưrazem na ochranu duševního vlastnictví. Praha: Wolters Kluwer, 2016, s. 80-81 ISBN: 978-80-7552038-8.

${ }^{72}$ K ochraně počítačových programů zmiňme rovněž zákon o počítačích z roku 1995, který se ovšem nevztahuje $\mathrm{k}$ ochraně počítačových programů stejným způsobem jako právo patentové či autorské, ale je součástí trestního práva, kdy např́íklad definuje některé skutkové podstaty spojené $s$ tvorbou a použitím počítačových programů, jež mohou způsobovat škodu (např. viry). Obecně se tedy zabývá kyberzločinem, kdy stanovuje postihy za jednání, která ohrožují počítačová data včetně zásahu do počítačových programů.

${ }^{73}$ Pojem zakotvený v Úmluvě o udělování evropských patentů. 
zahrnuje, přistupuje Izrael v některých případech $\mathrm{k}$ možnosti rovněž počítačový program patentovat. Aby mohl být počítačový program patentovatelný, musí obnášet reálný účinek, a tudíž splňovat podmínku technologické užitečnosti.

Ve srovnání s EPO je Izrael ve svém právním předpisu poněkud benevolentnější co se týče patentovatelnosti počítačových programů, ale podle posledního vývoje metodiky IPÚ je nutné podotknout, že se Izrael spíše přiklání k systému EPO. Teoreticky lze vycházet z faktu, že, pokud je počítačový program patentovatelný dle EPÚ, je patentovatelný i před IPÚ. Jak se tento metodický prríklon $\mathrm{k}$ evropskému systému projeví $\mathrm{v}$ praxi, bude třeba dále sledovat.

\subsection{OCHRANA PRŮMYSLOVÝCH VZORŮ}

$\mathrm{V}$ současné době probíhá v Izraeli příprava nové právní úpravy na ochranu průmyslových vzorů, která by měla nahradit dosud používaný, však z hlediska funkčnosti velmi zastaralý, původní předpis z roku 1924 v překladu $\mathrm{s}$ názvem Designová ustanovení - předpis o patentech a průmyslových vzorech $z$ roku $1924^{74}$ doplněný v procesních otázkách předpisem s názvem Designová pravidla z roku $1925^{75}$. Jak již bylo úvodem zmíněno, je Izrael členem všech významných mezinárodních smluv a v souvislosti s mezinárodní registrací průmyslových vzorů i Haagské dohody o mezinárodním přihlašování průmyslových vzorů a modelů.

Ochrana pomocí průmyslového vzoru je svým způsobem velmi specifická, protože na rozdíl od vynálezů nespočívá v ochraně řešení technické povahy. Dle $\S 1$ předpisu o designu se chráněný předmět definuje jako tvar, uspořádání, vzor či ornament užitý na jakémkoliv předmětu bez ohledu na způsob průmyslového postupu, čímž je dána podmínka tzv. výjimka z funkčnosti. Dále musí průmyslový vzor splňovat podmínku užitečnosti neboli průmyslové využitelnosti, jinak by jej bylo možné na základě jeho

${ }_{74}$ Viz Designová ustanovení - předpis o patentech a průmyslových vzorech z roku 1924. In: WIPO lex. [online]. [cit. 27. 3. 2017] Dostupné z: http://www.wipo.int/wipolex/en/text.jsp?file_id $=202111$

75 Viz Designová pravidla z roku 1925. In: WIPO lex. [online]. [cit. 27. 3. 2017] Dostupné z: http://www.wipo.int/wipolex/en/text.jsp?file_id $=343760$ 
vizuální podoby chránit dle autorského zákona jako autorské dílo. Třetí podmínkou pro zápis designu je jeho novost, jíž je na závadu již dříve zapsaný shodný vzor na národní úrovni. I u institutu průmyslového vzoru je na závadu novosti zveřejnění designu před datem podání přihlášky, zveřejnění je dle judikatury definováno nejen jako představení a popis designu, ale i schopnost jej napodobit. ${ }^{76}$

Doba ochrany je stanovena na 5 let od podání přihlášky a zápisné řízení trvá zpravidla 6 měsíců a $\mathrm{v}$ rejstř́íku zapsané designy se uveřejní 2 roky po zápisu - náhled je možný jen na základě svolení majitele ochrany, IPÚ či soudu. Oproti české právní úpravě nehovoří izraelská explicitně o tzv. individuální povaze průmyslového vzoru jako samotné podmínce zápisné způsobilosti, faktem však je, že tato podmínka je zahrnuta do zkoumání prověřující podmínku novosti. Další aspektem, který poukazuje na rozlišnost od českého, resp. evropského systému posuzování zápisné způsobilosti, je termín informovaného uživatele, jenž je fiktivní osoba zkoumající právě podmínku novosti. Izraelská právní úprava hovoří o tzv. průměrném uživateli, který však není osobou znalou oblastí průmyslových vzorů, jež by mohlo vést $\mathrm{k}$ opomenutí některých znaků při zkoumání novosti přihlašovaného vzoru vưči starším vzorům. ${ }^{77}$

\section{PRÁVNÍ OCHRANA PRÁV NA OZNAČENÍ A NEKALÁ SOUTĚŽ}

$\mathrm{V}$ této kapitole bude věnována pozornost právům na označení, které zastávají významné místo v oblasti průmyslově právní ochrany v Izraeli. Předmětem budou nejen registrované ochranné známky, kdy je majiteli poskytnuta ochrana již samotným zápisem označení do příslušného rejstř́ku, pokud je označení způsobilé takového zápisu, ale nezůstanou pominuty také známky neregistrované, které je možné v Izraeli za určitých podmínek rovněž chránit. Zde se zaměřím na všeobecně známé známky z důvodu jejich odlišné právní úpravy od kontinentální právní koncepce systému, kterou nalézáme například $\mathrm{v}$ právu českém. Všeobecně známé známky mohou

\footnotetext{
${ }^{76}$ Viz LISS, Eran a ADIN, Dan. Intellectual property law and practice in Israel. New York: Oxford University Press, 2012. s. 139-155 ISBN: 978-019-9917-419.

77 Tamtéž.
} 
být bud' zapsané, anebo nezapsané, které za určitých okolností mohou dosáhnout širší ochrany než zaregistrované ochranné známky v důsledku jejich známosti na straně izraelské spotřebitelské veřejnosti.

Tyto známky budou diskutovány v samostatné podkapitole, stejně jako mimosmluvní deliktní právo, které je typické pro státy založené na tzv. common law a úzce souvisí s právy na označení.

\subsection{LEGISLATIVA A PRÁVNÍ PRAMENY PRÁV NA OZNAČENÍ}

Počátky předpisu o ochranných známkách na území dnešního Státu Izrael vychází z původní britské úpravy z doby, kdy Palestina jako mandátní území byla pod správou Velké Británie (1918 - 1948). Izraelské právní prameny práv na označení tak historicky vychází ze zákonů Spojeného království, které obsahovaly $\mathrm{v}$ případě porušení práv plynoucí z ochranných známek občanskoprávní či trestně právní odpovědnost, jednalo se zejména o padělání či klamavé označení a další podvodná jednání.

Tento zákon byl však za svou dobu několikrát revidován, jednak z důvodu samotného rozvoje státu Izrael, ale také jeho aktivní účastí v mezinárodních úmluvách $\mathrm{v}$ oblasti duševního vlastnictví, které měly na formování izraelského práva významný vliv.

Jeden ze základních a zároveň nejdůležitějších právních pramenů v oblasti ochranných známek je předpis o ochranných známkách z roku $1972^{78}$. Jedná se o revidovanou verzi dříve platného právního předpisu (1938), který vychází ze základů britského práva z roku $1905 .{ }^{79}$ Tento předpis definuje obecná pravidla ve vztahu k ochranným známkám a mimo jiné řeší také občanskoprávní delikty $\mathrm{v}$ př́padě porušení ochranných zapsaných či nezapsaných všeobecně známých známek a vyvozuje trestněprávní odpovědnost pro určitý okruh nezákonných činností, které mohou být $\mathrm{v}$ rámci

78 Viz Předpis o ochranných známkách z roku 1972. In: WIPO lex. [online]. [cit. 27. 3. 2017] Dostupné z: http://www.wipo.int/wipolex/en/text.jsp?file_id = 341340

79 Viz FISCHMAN, Afori, Orit; GILAT, David; BAREKET, Eran; AFORI, Tamir. Intellectual property law in Israel. Alpen aan den Rijn: Kluwer Law International, 2013. s. 146 - 147 ISBN: 90-411-4859-0. 
tohoto předpisu stíhány způsobem trestního řízení také osobami soukromými. $^{80,81}$

Procesní otázky řízení u ochranných známek, jako jsou poplatky, klasifikace výrobků či jejich změna u již registrovaných ochranných známek nebo podání samotné přihlášky jsou řešeny $\mathrm{v}$ rámci nařízení o ochranných známkách z roku 1940.

Označení bez ohledu na jejich zápis mohou být ve státě Izrael chráněna prostřednictvím jednotlivých dílčích předpisů, které dohromady tvoří tzv. torts law, tedy zákony o mimosmluvních deliktech, které obsahují výčet specifických porušení. Ve vztahu k právům na označení se bude jednat zejména o „passing off“, „klamavé obchodní označeni““ (zákon o obchodních mimosmluvních deliktech), klamání spotřebitele“ (zákon o ochraně spotřebitele) či „bezdo̊vodné obohacení“ (zákon o bezdůvodném obohacení).

Stát Izrael je členem většiny významných mezinárodních dohod v oblasti duševního práva, mezi ty nejdůležitější patří: Pařížská úmluva na ochranu průmyslového vlastnictví (1883), Dohoda o obchodních aspektech práv k duševnímu vlastnictví TRIPS (1995), Protokol k Madridské dohodě o mezinárodním zápisu továrních nebo obchodních známek (1989) nebo Niceská dohoda o mezinárodním třídění výrobků a služeb pro účely zápisu známek (1957).

\subsection{ZNÁMKY}

Současný právní předpis o ochranných známkách definuje známku jako písmena, číslice, slova, zařízení nebo jiné znaky, anebo jejich kombinace vyjádřené ve dvou nebo třech rozměrech. $Z$ výše uvedené definice je patrné, že zde zůstává určitá otevřenost pro pojem ,jiné znaky“ kdy si lze představit netradiční známky, jako jsou známky čichové, chutoové, hudební či pachové. Možnost takového zápisu dokládá také již dříve zapsaná hudební známka, která byla vyjádřená ve formě notového zápisu. ${ }^{82} \mathrm{~V}$ českém známkovém právu definici ,jiné znaky“ sice nenalezneme, ale dle tohoto

${ }^{80}$ Viz $§ 68$ Zákon o trestním řízení z roku 1982 In: WIPO lex. [online]. [cit. 27. 3. 2017] Dostupné z: http://www.wipo.int/wipolex/en/text.jsp?file_id $=367172$

81 Viz $§ 60$ Předpis o ochranných známkách z roku 1972. In: WIPO lex. [online]. [cit. 27. 3. 2017] Dostupné z: http://www.wipo.int/wipolex/en/text.jsp?file_id $=341340$ 
zákona může být ochrannou známkou jakékoliv označení, které je graficky znázornitelné, přičemž odborná literatura k tomu doplňuje, že nemusí jít vždy o grafické označení, ale postačí, pokud zde existuje alespoň jeden způsob možnosti vyobrazení takového označení a musí vykazovat rozlišovací způsobilost. Možnost zápisu zvukového označení jako ochranné známky potvrdil i Evropský soudní dvưr ve svém rozhodnutî. ${ }^{83}$

Předpis o ochranných známkách rozlišuje známky podle účelu jejich užití, rozeznává známky obchodní (Trade-Marks) pro osoby zabývající se obchodem či výrobou výrobků obsahující takové označení nebo známky služební (Service Marks) prostřednictvím kterých nabízejí své služby.

Izraelský patentový úřad nezkoumá, zda přihlašované označení v době podání přihlášky je již užíváno ve vztahu $\mathrm{k}$ výrobkům či službám pro které má být zapsáno. Dostačující je záměr osoby označení takovým způsobem užívat, nejedná se tedy o podmínku zkoumanou v době zápisu. ${ }^{84}$ Nicméně neužívání zapsané ochranné známky může být později důvodem pro její výmaz z rejstř́ku ochranných známek, pokud se prokáže, že známka nebyla využívána po dobu 5 let od jejího zápisu, aniž by proto existovaly důvody zvláštního zřetele. Následkem toho se může stát, že vlastník starší ochranné známky nemůže namítat proti zápisu mladší ochranné známky v případě, že nedošlo $\mathrm{k}$ jejímu řádnému užívání, tím je myšleno také, aby známka byla užívána pro takové výrobky či služby, pro které byla zapsána.

${ }^{82}$ Viz FISCHMAN, Afori, Orit; GILAT, David; BAREKET, Eran; AFORI, Tamir. Intellectual property law in Israel. Alpen aan den Rijn: Kluwer Law International, 2013. s. 150 ISBN: 90-4114859-0.

${ }^{83}$ ESD ve svém rozhodnutí prohlásil, že je označení schopné takového zápisu, pokud je graficky vyjádřeno $\mathrm{v}$ notové osnově, rozdělené na takty a s uvedením notového klíče, not, případně jiných hudebních znamének, tak že jako celek představuje zachycení notové sekvence, tvořící melodii, která je nutná pro takový zápis. Viz Rozsudek ESD č. C-283/01 ve věci Shield Mark BV proti Joost Kist h.o.d.n. Memex In: EUR-lex [online]. [cit. 27. 3. 2017] Dostupné $\quad$ z: $\quad$ http://eur-lex.europa.eu/legal-content/EN/TXT/?uri = CELEX \%3A62001CJ0283

${ }^{84}$ Naproti tomu v USA se setkáváme s naprosto odlišným př́stupem, kdy jedna z podmínek pro úspěšný zápis označení do rejstř́ku ochranných známek představuje užívání takové známky v době podání přihlášky anebo písemné prohlášení přihlašovatele o úmyslu užívat ochrannou známku v rámci obchodní činnosti v USA („Declaration of Intention to Use the Mark"). 
Izraelské právo umožňuje ochranu také známkám kolektivním, odlišující výrobky nebo služby pocházející od členů, společníků právnické osoby nebo účastníků sdružení, majících zájem o výrobky či služby označené takovou známkou a jejichž záměrem je užívání označení pro takové výrobky či služby. Dále pak známkám certifikačním, které představují v izraelském právu typický prvek anglo-amerického právního systému a jsou tak v těchto státech považovány za tradiční známky. Slouží k odlišení výrobků či služeb, které byly majitelem certifikovány pro jejich materiál, povahu, kvalitu, způsob výroby nebo jinou vlastnost na základě čehož se odlišili od těch výrobků či služeb, které certifikovány nebyly. V podstatě se jedná o standardní ochranné známky, rozšířené pouze o takové vlastnosti, pro které byla ochranná známka certifikována. ${ }^{85}$ Vlastníkem nesmí být osoba vykonávající podnikatelskou činnost ve smyslu dodávání výrobků či poskytování služeb, které byly certifikovány. Pro účely zápisu certifikačních známek se nevyžaduje rozlišovací způsobilost, majitel však musí prokázat certifikované vlastnosti. $^{86}$

Označení (s výjimkou certifikačních známek) je schopné zápisu jako ochranné známky do rejstříku, pokud splňuje jednu ze základních podmínek, kterou je rozlišovací způsobilost, hodnotící z pohledu průměrného spotřebitele, tedy takové osoby, vykazující běžnou inteligenci a schopnou si tak určité označení spojit s konkrétním výrobkem či službou. ${ }^{87}$

Judikatura na tomto základě připouští čtyři hlavní kategorie ochranných známek:

Známky obecné: vyjadřují pouze obecnou informaci o jaký výrobek nebo službu se jedná a jsou vyloučeny ze zápisu. Navíc v rámci existence druhotného významu zakládají nezpůsobilost k zápisu jako ochranných známek, jak bylo soudy dříve stanoveno. ${ }^{88}$

${ }^{85}$ Certifikační známky bude nově možné získat i pro území ČR na základě významné změny v rámci známek EU

${ }^{86}$ Viz Předpis o ochranných známkách z roku 1972. In: WIPO lex. [online]. [cit. 27. 3. 2017] Dostupné z: http://www.wipo.int/wipolex/en/text.jsp?file_id = 341340

${ }^{87}$ Viz LISS, Eran a ADIN, Dan. Intellectual property law and practice in Israel. New York: Oxford University Press, 2012. s. 164 ISBN: 978-019-9917-419. 
Známky popisné: vyjadřují povahu nebo kvalitu, pro kterou může být známka spojována ve vztahu k výrobkům či službám jí označované. Pro způsobilost zápisu jako ochranné známky je nezbytné prokázat její druhotný význam, tedy možnost asociace takové známky s jejím vlastníkem. Obecně platí, že čím vyšší rozlišovací způsobilosti známka dosahuje, tím je taková asociace jednodušší. $\mathrm{V}$ opačném případě může pro jeho vlastníka představovat těžké důkazní břemeno. K prokázání druhotnému významu je soudní judikaturou považováno předložení takových důkazů, aby bylo možné prokázat dostatečnou známost takového označení a tím odlišení od ostatních známek na straně veřejnosti, přičemž váha a úroveň jednotlivých označení se může lišit v závislosti na povaze dotčeného označení. $^{89}$

Známky náznakové: vyjadřují pouze náznak ve vztahu $\mathrm{k}$ výrobkům či službám s absencí přímého popisu. Na známky se pohlíží jako na známky mající rozlišovací způsobilost a proto jsou schopné zápisu.

Známky náhodné: nevykazují žádný vztah $\mathrm{k}$ výrobkům či službám, $\mathrm{v}$ rámci kterých mají být užívány. Mohou to být jak známky fantazijní tak nesmyslné, $\mathrm{v}$ některých případech obsahující jednoznačná slova, z kterých není možné poznat $\mathrm{k}$ jakému výrobku, anebo službě se vztahují, jako tomu je v př́ípadě známek obecných.

\subsection{ABSOLUTNÍ A RELATIVNÍ DŮVODY ZÁPISNÉ NEZPŮSOBILOSTI}

Izraelský právní předpis o ochranných známkách vymezuje podmínky zápisné způsobilosti spíše negativním způsobem ${ }^{90}$. Ačkoliv § 8 izraelského zákona o ochranných známkách se nazývá pozitivně „známky způsobilé $\mathrm{k}$ registraci“, tyto známky jsou následně vymezeny spíše negativně. Za účelem zjištění, zda určité označení je schopné zápisu, je nutné zkoumat pře-

88 Viz. Rozhodnutí Nejvyššího soudu v Jeruzalémě 2673/04 Coffee To Go Ltd. proti Israel Shaked In: Nejvyšší soud v Jeruzalémě [online]. [cit. 27. 3. 2017] Dostupné z: http://elyon1.court.gov.il/files/04/730/026/Z07/04026730.z07.pdf

89 Viz. Rozhodnutí Nejvyššího soudu v Jeruzalémě 3559/02 Toto Zahav Members Club Ltd. proti The Sports Gambling Council In: Nejvyšší soud v Jeruzalémě [online]. [cit. 27. 3. 2017] Dostupné z: http://elyon1.court.gov.il/files/02/590/035/N18/02035590.n18.pdf

$90 \mathrm{~S}$ výjimkou zmiňované definice známky $\mathrm{v}$ preambuli předpisu o ochranných známkách $\mathrm{z}$ roku 1972. 
devším negativní vymezení, tedy co ochrannou známkou nemůže být na základě výčtu absolutních a relativních překážek zápisné způsobilosti. ${ }^{91}$

Absolutní důvody zápisné nezpůsobilosti: jsou takové, pro které je označení automaticky vyloučeno ze zápisu do rejstříku ochranných známek a to bez ohledu na skutečnost, zda k přihlašovanému označení existují i jiná práva, jako např́ílad práva třetích osob plynoucí ze starší ochranné známky pro stejné výrobky či služby nebo všeobecně známé známky. Jedná se o důvody vyplývající ze samé podstaty a povahy označení, které by v důsledku zápisu mohlo společnost klamat či ji uvést v omyl z důvodu potencionálně klamavé povahy označení.

Absolutními důvody, na základě kterých IPÚ vyloučí označení ze zápisu, mohou být následující:

1) odkazuje na spojení s prezidentem Státu Izrael, poukazuje na vztah se Státem Izrael nebo jakékoliv označení schopné vyvolat takový dojem,

2) obsahuje erby, emblémy států, státních institucí, jakožto meziná rodních organizací,

3) je tvořeno symboly náboženské hodnoty,

4) objevují se v něm slova jako „Patent“, „Patented“, „By Royal Letters Patent“, „Registered“, „Registered Design“, „Copyright“ anebo imi tace těchto slov,

5) by mohlo klamat společnost o původu výrobku, jejich povaze či kvalitě, pokud se jedná o nepravdivý zeměpisný údaj, je nejdříve nutné posoudit, zda označení vykazuje souvislost s výrobky či služ bami jím označované, jelikož v př́ípadě, že je označení ve své pod statě fantazijní nepředstavuje tak důvod pro jeho vyloučení ze zápi $\mathrm{su}^{92}$

6) je či může být $v$ rozporu s dobrými mravy nebo veřejným pořádkem,

91 Viz § 11 Předpis o ochranných známkách z roku 1972. In: WIPO lex. [online]. [cit. 27. 3. 2017] Dostupné z: http://www.wipo.int/wipolex/en/text.jsp?file_id $=341340$

92 Viz. Rozhodnutí Nejvyššího soudu v Jeruzalémě 10959/05 Tea Board, India proti Delta Lingerie S.A.OF Chachan. 
7) je přihlašováno pro víno či lihoviny, přičemž obsahuje zeměpisné označení, které neodpovídá takovému původu. ${ }^{93}$

Relativní důvody zápisné nezpůsobilosti: představují práva třetích osob, která mohou existovat ve vztahu $\mathrm{k}$ přihlašovanému označení, které by tak $\mathrm{v}$ př́padě jeho zápisu bylo $\mathrm{v}$ kolizi $\mathrm{s}$ těmito právy. Přihlašované označení předpokládá vlastnická práva $\mathrm{k}$ ochranné známce nejčastěji přihlašovateli, at už jde o fyzickou či právnickou osobu, která takové podání u IPÚ učinila, přitom se nemusí vždy jednat o jediný subjekt, ale může jít i o více osob. Skutečným majitelem neboli vlastníkem takových práv však může být osoba odlišná od osoby přihlašovatele, která proti takovému zápisu může podat námitky. Stejně jako v zákoně o ochranných známkách platného v České republice je nutno tyto námitky podat písemně, ve stanoveném časovém rozmezí a doložit důkazy na podporu takového tvrzení. Přihlašované označení se nezapíše do rejstř́íku nejčastěji v případech kdy:

Je shodné či podobné se starší registrovanou ochrannou známkou, pokud je přihlašováno pro stejné výrobky či služby. Smyslem tohoto ustanovení je předejít újmě, která by mohla být způsobena vlastníkovi starších práv takovým zápisem a uvedení spotřebitelské společnosti v omyl tím, že by zde mohlo dojít $\mathrm{k}$ pravděpodobnosti záměny takových označení na straně veřejnosti.

Je shodné či podobné registrované či neregistrované všeobecně známé známce, i navzdory tomu, že není přihlašováno pro stejné výrobky či služby, ale vzhledem k tomu, že jde o všeobecně známou známku, která má dobré jméno na území státu Izrael, mohl by takový zápis poukazovat na vztah mezi těmito známkami, v důsledku čehož by mohla být všeobecně známá známka nepříznivě ovlivněna ${ }^{94}$

Je shodné nebo podobné jménu či obchodní firmě jiné osoby a je pravděpodobné, že by mohlo dojít ke klamání veřejnosti, anebo naplnění aspektů nekalé soutěže takovým zápisem. ${ }^{95}$

93 Viz § 11 Předpis o ochranných známkách z roku 1972. In: WIPO lex. [online]. [cit. 27. 3. 2017] Dostupné z: http://www.wipo.int/wipolex/en/text.jsp?file_id $=341340$

94 Viz § 11 odst. 14 Předpis o ochranných známkách z roku 1972. In: WIPO lex. [online]. [cit.27. 3. 2017] Dostupné z: http://www.wipo.int/wipolex/en/text.jsp?file_id $=341340$ 
Posuzování „matoucí podobnosti“ na základě tzv. trojnásobného testu (Three-Fold Test) bylo soudy poprvé vysloveno v souvislosti s žalobami na passing off, které se týkají výhradně práv na označení, jak bude později vysvětleno. $\mathrm{V}$ rámci tohoto testu jsou zkoumány následující aspekty pro posouzení podobnosti u sporných označení: i) rozsah podobnosti z hlediska vizuálního a zvukového, ii) povaha výrobku a jejich známost na straně spotřebitelské veřejnosti, iii) jakékoliv další relevantní skutečnosti. ${ }^{96}$ Hlavním kritériem takového hodnocení je zda spotřebitelé vykazující běžnou inteligenci a jednající tak s obvyklou obezřetností by mohli být i přesto zmateni, pokud jde o výrobky či služby ve vztahu $\mathrm{k}$ jeho vlastníkovi. ${ }^{97}$ České právo v posuzování zaměnitelnosti vychází z rozhodovací praxe Úřadu průmyslového vlastnictví a soudů, které prvně zakotvili konkrétní kritéria pro posuzování podobnosti mezi dotčenými známkami. Jedná se o hledisko vizuální, fonetické a významové, přičemž podobnost může být prohlášena i $\mathrm{v}$ př́padě, že dojde $\mathrm{k}$ naplnění jediného hlediska. Izrael $\mathrm{z}$ tohoto pohledu přistupuje $\mathrm{k}$ otázce zaměnitelnosti o něco flexibilněji, kdy soudy může být $\mathrm{v}$ př́ípadě sporných řízení zohledněn $\mathrm{v}$ podstatě jakýkoliv aspekt, který považují za relevantní s ohledem na povahu dotčených označení.

\subsection{VŠEOBECNĚ ZNÁMÉ ZNÁMKY}

Obecně platí, že známka vzniká jejím užíváním pro dané výrobky nebo služby a naopak ochranná známka jejím zápisem do rejstř́ku ochranných známek vedeného u IPÚ. Všeobecně známá známka však představuje známku natolik silnou, že se vžila pro určité výrobky či služby svého vlastníka do povědomí př́slušného okruhu společnosti do té míry, že získala rozlišovací způsobilost a to i přesto, že nedošlo k jejímu formálnímu zápisu.

\footnotetext{
95 Viz § 12 Předpis o ochranných známkách z roku 1972. In: WIPO lex. [online]. [cit. 27. 3. 2017] Dostupné z: http://www.wipo.int/wipolex/en/text.jsp?file_id = 341340

96 Viz LISS, Eran a ADIN, Dan. Intellectual property law and practise in Israel. Oxford University Press, Inc., 2012. s. 260 ISBN: 978-019-9917-419.

97 Viz Rozhodnutí Oblastního soudu v Tel Avivu 476/82 Orlogad Ltd. proti Registrar of Trade Mark In: Lawdata.co.il [online]. [cit. 27. 3. 2017] Dostupné z: http://www.lawdata .co.il/printDoc.asp $? \mathrm{c}=484763 \&$ mador $=$ psak\&IskurHokIndx $=$ \&IskurHokSeif $=$ \&note $=$ $\& d t=1488845100000$
} 
V izraelském právním pojetí všeobecně známých známek můžeme spatřit zásadní rozdíl oproti právu českému, které vychází z evropské kontinentálně právní koncepce a rozeznává tak registrované ochranné známky s dobrým jménem s možností rozšíření ochrany nad rámec výrobků či služeb pro které byla zapsána, pokud se prokáže, že známka si svým užíváním získala patřičné renomé (označované jako „dobré jméno“, „dobrá pověst“) na straně české spotřebitelské veřejnosti, která si tyto výrobky nebo služby spojuje s dobrými vlastnostmi a známky neregistrované všeobecně známé, které mohou být chráněny pro takové výrobky či služby, pro které se staly známé příslušnému okruhu veřejnosti. Avšak ochrana všeobecně známé známky může být za určitých okolností rozšířena na všechny výrobky či služby za podmínky, že všeobecně známá známka získala navíc i dobré jméno u relevantní části spotřebitelské veřejnosti. Známka s dobrým jménem tak představuje širší ochranu než známka všeobecně známá (s výjimkou všeobecně známé známky s dobrým jménem). Izrael však takové rozdělení ve svém právu postrádá a všeobecně známé známky zahrnují i známky s dobrým jménem. Z tohoto hlediska izraelské právo obsahuje mnohem jednoduší právní úpravu, která rozeznává pouze mezi známkami zapsanými všeobecně známými, které mohou být chráněny v rozsahu nám známých ochranných známek s dobrým jménem a známky všeobecně známé neregistrované, které odpovídají rozsahu ochrany, kterou nalézáme v naší právní úpravě u těchto známek.

Všeobecně známé známky mohou být chráněny prostřednictvím obecného předpisu o ochranných známkách, přičemž tato právní úprava vychází z ustanovení upravující všeobecně známé známky obsažené $\mathrm{v}$ dohodě TRIPS $^{98}$, která byla implementována do izraelského práva $\mathrm{v}$ návaznosti na přístup státu Izrael k této dohodě dne 21.4.1995. Všeobecně známá známka je v rámci tohoto předpisu definována jako známka, která je všeobecně známá ve státě Izrael bez ohledu na to, zda došlo k jejímu zápisu a je ve vlastnictví osoby, která je občanem či má trvalé bydliště ve státě, který je členem Pařížské unijní úmluvy (PÚÚ) nebo Světové obchodní organizace

98 Agreement on Trade-Related Aspects of Intellectual Property Rights (TRIPS Agreement). 
(WTO) či v takovém státě provozuje aktivně obchodní nebo průmyslový podnik.

Přínosem této dohody je i stanovení možnosti dosáhnutí rozšířené ochrany nad rámec výrobků nebo služeb, pro které je všeobecně známá známka zapsána či užívána. Izraelské známky mohou využívat rozšîřené ochrany v rámci území státu Izrael. $\mathrm{V}$ případě zahraničních všeobecně známých známek $\mathrm{v}$ souladu s právem izraelským je ochrana omezena $\mathrm{v}$ rozsahu výrobků nebo služeb, pro které je tato známka v zahraničí užívána. $\mathrm{V}$ některých případech je přípustné, aby zahraniční známka, která i přesto, že není užívána v Izraeli, zde byla považována za všeobecně známou známku, pokud se prokáže, že získala pověst na izraelském trhu. ${ }^{99}$ Samotná registrace a užívání známky však nejsou předpokladem pro prohlášení ochranné známky za všeobecně známou, je nutné mít uznání ze strany izraelské veřejnosti.

Všeobecně známé známky získávají odlišný rozsah ochrany podle toho, zda jsou registrované či neregistrované. Zapsané všeobecně známé známky jsou chráněny proti konfliktním známkám jiného vlastníka pro výrobky či služby, které mohou být odlišného popisu, zatímco ty neregistrované mohou svou ochranu uplatnit pouze proti známkám znějící na stejný popis výrobků či služeb. ${ }^{100}$

Posuzování, zda určité označení dosáhlo statusu všeobecně známé známky je plně v jurisdikci př́slušného úřadu či soudu. Neexistují tedy obecně platná pravidla, která by stanovila podmínky, za nichž se známka stává všeobecně známou. Ke každému případu se musí přistupovat individuálně. Hodnotí se rovněž, do jaké míry se stala známka všeobecně známou $\mathrm{v}$ příslušných kruzích veřejné společnosti a do jaké míry to bylo dáno masivní reklamou či marketingem. $\mathrm{V}$ případě sporu v otázce posouzení nebezpečí spojitosti mezi všeobecně známou známkou a spornou známkou je nutné prokázat, že sporné označení je schopné vyvolat představu v kruzích

\footnotetext{
99 Viz FISCHMAN, Afori, Orit; GILAT, David; BAREKET, Eran; AFORI, Tamir. Intellectual property law in Israel. Alpen aan den Rijn: Kluwer Law International, 2013. s. 163 ISBN: 90-4114859-0.

${ }^{100}$ Viz LISS, Eran, ADIN, Dan. Intellectual property law and practise in Israel. Oxford University Press, Inc., 2012. s. 260 ISBN: 978-019-9917-419.
} 
spotřebitelské společnosti na spojení s všeobecně známou známkou vlastníka a zápisem sporné známky by mohlo dojít $\mathrm{k}$ újmě na straně tohoto vlastníka. Nebezpečí asociace s všeobecně známou známkou se však liší v závislosti na prokázaném stupni rozlišovací způsobilosti. To dokládá také rozhodnutí Nejvyššího soudu, který prohlásil, že všeobecně známá známka skládající se z pochvalného slova (ABSOLUT for vodka) nepředstavuje překážku v zápisu takového slova v rámci jiné známky pro odlišnou kategorii výrobků, $\mathrm{v}$ tomto případě (Absolute Shoes). ${ }^{101} \mathrm{~V}$ posuzování nebezpečí asociace je nezbytné zohlednit řadu aspektů, pokud je tedy shledána podobnost mezi dvěma označeními, je nutné také přihlédnout $\mathrm{k}$ tomu, $\mathrm{v}$ jakém obchodním odvětví se sporná označení užívají, zda si vzájemně konkurují nebo se doplňují, a zda zde existuje pravděpodobnost jakéhokoliv spojení na straně veřejnosti.

\subsection{OBČANSKÉ A OBCHODNÍ MIMOSMLUVNÍ DELIKTY}

S mimosmluvními delikty se setkáváme v oblasti práv na označení, at zapsaných či nezapsaných, potažmo v celé oblasti duševního vlastnictví. Jedná se tedy o právní institut $\mathrm{s}$ širokou působností, o kterém obecněji hovoří kapitola první.

\subsubsection{NEKALÁ SOUTĚŽ}

Ochrana práv na označení bývá ze všech právních institutů průmyslového vlastnictví nejčastěji řešena $\mathrm{v}$ př́ípadech nekalé soutěže. $\mathrm{Z}$ toho důvodu jsou pro nás nejdůležitější následující zákony, které se nekalou soutěží zabývají a prostřednictvím kterých je možné vyvozovat následky z porušování těchto práv bez ohledu na skutečnost, zda došlo $\mathrm{k}$ jejich zápisu či nikoliv. Předpokladem je naplnění skutkových podstat, na základě kterých je možné určité jednání označit jako tort.

\subsubsection{ZÁKON O OBCHODNÍCH MIMOSMLUVNÍCH DELIKTECH}

Zákon o obchodních mimosmluvních deliktech je v oblasti duševního vlastnictví a konkrétně ve spojení s právy na označení považován za nejdů-

${ }^{101}$ Viz. Rozhodnutí Nejvyšší soudu v Jeruzalémě 9191/03 V\&S Vin \& Spirt Aktiebolag proti Absolute Shoes Ltd In: Nevo [online]. [cit. 27. 3. 2017] Dostupné z: http://www.nevo.co.il/Psika_word/elyon/0309191.doc 
ležitější. Tento zákon je v platnosti od roku 1999 a dotýká se významně práv na ochranu před nekalou soutěží. Obsahuje právní úpravu deliktů „passing off" a „klamavé označení“.

1) Tort passing off se vztahuje na práva na označení bez ohledu na absenci zápisu a bývá tak nejčastějším žalobním důvodem v soudních sporech $\mathrm{v}$ této oblasti. $\mathrm{V}$ českém právu je možné ho přiřadit ke skutkové podstatě „Vyvolání nebezpečí záměny“ v § 2981 NOZ. Zákonem je definováno, že obchodník nezapříčiní, aby jeho výrobky nebo služby byly mylně považovány za výrobky nebo služby jiného obchodníka, popř́ípadě výrobky či služby spojené s jiným obchodníkem. ${ }^{102}$ Tento tort byl dříve součástí jiného právního předpisu v odlišném znění, konkrétně se jednalo o předpis o mimosmluvních deliktech z roku 1968, který však postrádal definici passing off, která by se vztahovala také na služby, teprve až po přijetí zákona o obchodních mimosmluvních deliktech, bylo uzákoněno, že je možné tento tort použít jak ve vztahu $\mathrm{k}$ výrobkům, tak $\mathrm{i}$ službám, smysl tohoto tortu však nezměněn. ${ }^{103}$

Primárním cílem tohoto ustanovení z pohledu soudnictví je chránit obchodní goodwill, kterého bylo dosaženo obchodníkem a tedy zachování jeho dobrého jména a pověsti pro určité výrobky či služby na straně veřejnosti. $\mathrm{V}$ návaznosti na tento výklad bylo judikaturou dovozeno, že proto, aby bylo určité jednání možné označit za passing off je nutné splnění dvou základních podmínek.

V prvé řadě se vyžaduje prokázání existence goodwill ve smyslu schopnosti asociace výrobků či služeb daného obchodníka s dobrými vlastnostmi ze strany veřejnosti. $\mathrm{V}$ druhé řadě musí být takové jednání způsobilé klamat, tato podmínka je nutná a zároveň dostačující, proto není rozhodující, zda k vyvolání klamavé představy u

\footnotetext{
${ }^{102}$ Viz § 1 Zákon o obchodních mimosmluvních deliktech z roku 1999 In: WIPO lex. [online]. [cit. 27. 3. 2017] Dostupné z: http://www.wipo.int/wipolex/en/text.jsp?file_id = 128056

${ }^{103}$ Viz FISCHMAN, Afori, Orit; GILAT, David; BAREKET, Eran; AFORI, Tamir. Intellectual property law in Israel. Alpen aan den Rijn: Kluwer Law International, 2013, s. 191 ISBN: 90-4114859-0.
} 
zákazníka došlo či nikoliv, podstatné je zda zde existuje pravděpodobnost, že by k ní mohlo takovým jednáním dojít.

Naplnění obou aspektů skutkové podstaty passing off se jeví obtížné zejména ve chvíli, kdy žalobcem je majitel nezapsaného označení, který tak nese náročnější důkazní břemeno, na rozdíl od majitele, který má označení registrované jako ochrannou známku a tudíž se zde předpokládá vlastnictví $\mathrm{k}$ takové známce a proces prokazování je tak mnohem jednodušší.

Tento způsob ochrany je uplatňovaný především k právům na označení. S ohledem na historickou povahu tohoto tort, není možné $\mathrm{v}$ rámci passing off uplatňovat ochranu ve vztahu $\mathrm{k}$ výsledkům technické tvưrčí činnosti, což představuje významný rozdíl od práva českého, kdy ustanovení o vyvolání nebezpečí záměny je možné užít na ochranu vzhledu výrobků po stránce designu. Nejvyšší soud v Izraeli však již dř́ve vynesl otázku, zda by alespoň designy vykazující rozlišovací způsobilost nemohly uplatňovat ochranu skrze tento právní institut. Takové rozšiřrení na technické oblasti však bylo jednoznačně vyloučeno $\mathrm{v}$ budoucnu. Pokud by však $\mathrm{k}$ němu někdy $v$ budoucnu přeci jen došlo, představovalo by to revoluční změnu v současném izraelském právu v oblasti ochrany práv průmyslového vlastnictví.

2) Tort klamavé označení představuje jednání, kdy obchodník zveřejní takové označení vztahující se na určité výrobky či služby, o kterém ví či by měl vědět s ohledem na povahu takového označení, že je nepravdivé a je způsobilé klamat veřejnost. Může se jednat o klamavé označení v souvislosti s výrobky nebo službami jiného soutěžitele ${ }^{104}$, přičemž je v ustanovení doplněno, že osoby či inzerenti budou odpovědni za takové jednání, pokud věděli o nepravdivosti, klamavosti tohoto označení. ${ }^{105}$

\footnotetext{
${ }^{104}$ Viz § 2 písm. a Zákon o obchodních mimosmluvních deliktech z roku 1999 In: WIPO lex. [online]. [cit. 27. 3. 2017] Dostupné z: http://www.wipo.int/wipolex/en/text.jsp? file_id $=128056$
} 
3) Zákon na ochranu spotřebitele je zákon, který vstoupil v účinnost dne 1. 8. 1981 a zabývá se ochranou práv v hospodářské soutěži ve vztahu ke spotřebiteli a také obchodními názvy. ${ }^{106}$ Je spravován $\mathrm{v}$ rámci zákona o obchodních mimosmluvních deliktech. V části druhé tohoto ustanovení nazvaném jako „Spotřebitel nesmí být uveden v omyl“ je stanoveno, že obchodník nesmí, at už jednáním či jeho pochybením bez ohledu na formu provedení takového jednání (písemně, ústně nebo jakýmkoliv jiným způsobem) vyvolat mylnou představu spotřebitele ve vztahu $\mathrm{k}$ výrobkům či službám o jejich kvalitě, druhu, množství nebo rozměrech, hmotnosti, tvaru či místa výroby takových výrobků. ${ }^{107}$ Tuto skutkovou podstatu v českém právu je možné připodobnit $\mathrm{k}$ ustanovení o klamavém označení zboží nebo služby v $§ 2978$, které je zpơsobilé rovněž klamat ve vztahu $\mathrm{k}$ původu, povahy nebo jakosti takového zboží či služeb. $^{108}$

\subsubsection{ZÁKON O BEZDU゚VODNÉM OBOHACENÍ}

Zákon o bezdůvodném obohacení je vedle zákona o obchodních deliktech a zákona na ochranu spotřebitele dalším dílčím zákonem, který se také zabývá ve svých ustanoveních otázkami nekalé soutěže a definuje tort bezdi̊vodného obohacení. Ve státě Izrael je v účinnosti od roku 1979 a představuje významný nástroj ochrany zejména $\mathrm{v}$ případech, kdy není možné

${ }^{105}$ Viz § 2 písm. b Zákon o obchodních mimosmluvních deliktech z roku 1999 In: WIPO lex. [online]. [cit. 27. 3. 2017] Dostupné z: http://www.wipo.int/wipolex/en/text.jsp? file_id $=128056$

${ }^{106}$ Viz Zákon o ochraně spotřebitele $\mathrm{z}$ roku 1981 In: WIPO lex. [online]. [cit. 27. 3. 2017] Dostupné z: http://www.wipo.int/wipolex/en/text.jsp?file_id = 128084

${ }^{107}$ Viz $\S 2$ Zákon o ochraně spotřebitele z roku 1981 In: WIPO lex. [online]. [cit. 27. 3. 2017] Dostupné z: http://www.wipo.int/wipolex/en/text.jsp?file_id = 128084

${ }^{108}$ Srov. § 2978 zák. č. 89/2012 Sb., občanský zákoník. In: Portál veřejné správy. [online]. [cit. 27. 3. 2017] Dostupné z: https://portal.gov.cz/app/zakony/zakonPar.jsp? idBiblio $=74907 \&$ fulltext $=$ autorsk $\sim \mathrm{C} 3 \sim \mathrm{BD} \sim 20 \mathrm{z} \sim \mathrm{C} 3 \sim \mathrm{A} 1 \mathrm{kon} \& \mathrm{rpp}=15 \#$ local-content

(1) Klamavé označení zboží nebo služby je takové označení, které je zpưsobilé vyvolat v hospodářském styku mylnou domněnku, že jím označené zboží nebo služba pocházejí z určité oblasti či místa nebo od určitého výrobce, anebo že vykazuje zvláštní charakteristický znak nebo zvláštní jakost. Nerozhodné je, zda označení bylo uvedeno bezprostředně na zboží, na obalu, obchodní písemnosti nebo jinde. Rovněž je nerozhodné, zda ke klamavému označení došlo př́mo nebo neprímo a jakým prostředkem se tak stalo. 
uplatňovat ochranu skrze jiné předpisy duševního vlastnictví či je to s ohledem na povahu takového jednání nepravděpodobné. Vzhledem k limitovanosti ochrany prostřednictvím ustanovení o passing off, které je tak možné uplatnit pouze ve vztahu k právům na označení, představuje tento předpis významný prostředek ochrany pro celou oblast duševního vlastnictví v otázkách nekalé soutěže.

Podstata právního institutu ochrany před bezdůvodným obohacením byla založena na třech základních aspektech, které musí být vždy současně naplněny. $\mathrm{V}$ opačném případě není možné takové jednání označit za bezdůvodné obohacení. Je nezbytné dokázat, že v důsledku tohoto jednání došlo $\mathrm{k}$ nějakému druhu prospěchu, dále že tak bylo dosaženo na úkor poškozeného, tedy žalobce a v poslední řadě bylo jednání bez zákonného nároku. Prokázání naplnění tř̌etího aspektu tohoto ustanovení představuje vůbec nejtěžší důkazní břemeno.

Kromě tohoto výkladu bylo v několika rozhodnutích Nejvyšším soudem dovozeno, že v případě obohacení není zákonem výslovně řečena ani výslovně odepřena otázka o tom, že to zda je obohacení zákonné či nikoliv závisí na otázce, zda je takové obohacení nespravedlivé. ${ }^{109}$ Je nutné také zmínit, že samotný předpis $v$ hebrejském znění, stejně jako $v$ anglickém, znamená nespravedlivé obohacení, ovšem v českém překladu se s ním setkáváme pod pojmem bezdůvodné obohacení.

Zásadní zlom ve výkladu bezdůvodného obohacení s ohledem na tuto vynesenou otázku učinil soudce Nejvyššího soudu Aharon Barak v případě A.Sh.I.R, když rozhodl, že s ohledem na širokou působnost tohoto ochranného prostř̌edku se jeví trři základní aspekty jako nedostatečné k tomu, aby bylo určité jednání možné považovat za bezdůvodné obohacení. Stanovil tedy čtvrtý, tzv. zvláštní element, který je nutný vykládat ve smyslu naplnění skutkové podstaty nekalé soutěže jednáním žalovaného,

${ }^{109}$ Viz. Články. Mondag.com. Unjust Enrichment (Restitution) - the Elements Necessary to Establish a Claim for Unjust Enrichment. [online]. Publikováno: 21.1.2005. [cit. 01.01.2017] Dostupné z: http://www.mondaq.com/x/30533/Product + Liability + Safety/Unjust + Enrichment + Restitutionthe + Elements + Necessary + to + Establish + a + Claim + for + Unjust + Enrichment. 
jednáním přičící se zásadám poctivého obchodu či jednání, které je konáno ve „zlé víre“" způsobem, který je v rozporu se spravedlností a poctivostí.

$\mathrm{V}$ př́stupu soudu tak shledáváme vysoký důraz, který je kladen na posuzování spravedlivosti v otázkách bezdůvodného obohacení. $\mathrm{V}$ praxi to může znamenat, že i jednaní, které bylo konáno na základě právního důvodu, ale bylo nespravedlivé s ohledem na získaný prospěch a povahu takového jednání, může být soudy prohlášeno za bezdůvodné obohacení. Nespravedlnost představuje v soudnictví států založených na common law významný rozhodovací prvek a odlišuje se tak od kontinentálně právního pojetí, které nalézáme $\mathrm{v}$ právu českém, kde se $\mathrm{v}$ posuzování bezdůvodného obohacení zkoumá, zda bylo jednání konáno bez právního důvodu a tedy nezákonně.

Izrael neobsahuje v porovnání s právem českým komplexní právní předpis upravující nekalou soutěž a v důsledku absence generální klauzule je možné vycházet pouze $\mathrm{v}$ rámci demonstrativního výčtu skutkových podstat upravených napřič samostatnými dílčími předpisy, které tak vnáší do rozhodování soudů v Izraeli více právní nejistoty než v právu českém. I přesto, že se př́ípad A.Sh.I.R. stal významným precedentem $\mathrm{v}$ otázkách posuzování nekalé soutěže $\mathrm{v}$ oblasti duševního vlastnictví, mají především soudy nižších stupňů problémy s výkladem jednotlivých skutkových podstat, což vnáší do těchto práv určitou právní nejistotu a soudy se tak $\mathrm{v}$ jednotlivých interpretacích mohou významně rozcházet. $\mathrm{Z}$ tohoto pohledu by bylo vítaným řešením, pokud by $\mathrm{v}$ budoucnu došlo $\mathrm{k}$ přijetí připraveného občanského zákoníku, který by nekalou soutěž vykládal komplexně v rámci jediného zákona, tak jako v právu českém (NOZ).

\section{ZÁVĚR}

Izraelský právní systém je přinejmenším dle názoru autorů systémem unikátním, který v sobě pojí mnoho odlišných prvků a historických i současných vlivů. Oblast práva duševního vlastnictví je jistě právním oborem velmi specializovaným, přesto je $\mathrm{v}$ případě zahraničního systému namístě poukázat také na základy a nosné prvky práva daného státu, ačkoli se může na první pohled zdát, že s právem duševního vlastnictví přímo nesouvisejí. 
Bez znalosti širších souvislostí by však bylo velmi obtížné porozumět charakteru právní ochrany duševního vlastnictví ve Státě Izrael.

Izraelské právo je proto $\mathrm{v}$ tomto článku představeno, byt velmi stručně, od počátků svého vývoje přes postupné změny, které s sebou nesla jednotlivá období. Článek se nicméně např́íklad oblasti občanského práva věnuje pouze částečně, a to $\mathrm{v}$ př́padě práva smluvního, které má $\mathrm{k}$ oblasti práva duševního vlastnictví poměrně těsnou vazbu, at již hovoříme o nakládání $\mathrm{s}$ právy $\mathrm{k}$ duševnímu vlastnictví či mimosmluvních deliktech. Hlavní zaměření tohoto článku je ovšem na samotnou oblast právní ochrany duševního vlastnictví, a to práv $\mathrm{k}$ výsledkům technické tvůrčí činnosti, jakou jsou vynálezy nebo průmyslové vzory a práva na označení z pohledu formálního i neformálního způsobu ochrany.

Bylo by chybou izraelské právo přehlížet jako pouhou odnož práva anglického vzhledem $\mathrm{k}$ tomu, jak bylo v článku popsáno, každá dílčí část práva i v rámci oboru duševního vlastnictví čerpá z odlišných vzorů, a setkáváme se poté $s$ dnes již velmi evropskou úpravou práva patentového a oproti tomu velmi americkým př́istupem k právu autorskému či právům na označení. Ani $\mathrm{v}$ jednom $\mathrm{z}$ těchto př́ípadů však nelze hovořit o přímé adopci právního vzoru, ale inkorporaci dílčích prvků vedoucích $\mathrm{k}$ vytvoření osobitého práva izraelského.

Od práva českého se izraelský přístup v mnoha ohledech odlišuje, jak ukazuje již kupř́kladu důraz na majetkovou podstatu autorských práv, která mohou být předmětem převodu, odlišné podmínky patentovatelnosti vynálezů zahrnujících i hledisko užitečnosti známé spíše ze systému amerického, přestože je nepř́mo uplatňováno i v systémech evropských, nebo princip vzniku práva na označení jeho užitím, kdy zápis ochranné známky má již charakter více deklaratorní než konstitutivní. Zajímavou skutečností je jistě také, že právo nekalé soutěže především ve vztahu k duševnímu vlastnictví je v izraelském systému poměrně roztřišstěno do skupiny dílčích zakázaných typů jednání bez obecnější sjednocující definice, za kterou bychom mohli považovat českou tzv. generální klauzuli.

$S$ rozvojem spolupráce mezi Českou republikou a Státem Izrael v oblasti výzkumné a technologické je tedy stále důležitější pro odborníky, jakými 
jsou advokáti a patentový zástupci, a stejně tak pro podnikatele nebo vědce, aby získaly alespoň základní přehled o fungování izraelského právního systému v oblasti právní ochrany duševního vlastnictví a tento článek má proto ambici k tomuto účelu také přispět.

\section{SEZNAM ZDROJU゚}

\subsection{MONOGRAFIE, ODBORNÉ ČLÁNKY, SBORNÍKY}

[1] AFORI, Orit Fischman; GILAT, David; BAREKET, Eran, AFORI, Tamir. Intellectual property law in Israel. Alphen aan den Rihn: Kluwer Law International, 2013. ISBN 90-411-4859-0.

[2] BAKER, Henry E. Legal System of Israel. Jeruzalém: Israel Universities Press, 1968. ISBN nepřiděleno.

[3] BIN-NUN, Ariel. The Law of the State of Israel. Jeruzalém: Rubin Mass, 1990. ISBN 9789650901127.

[4] BIRNHACK, Michael D. Colonial copyright: intellectual property in mandate Palestine. First edition. Oxford: Oxford University Press, 2012. ISBN 01-996-6113-8.

[5] BLAHOŽ, Jozef; BALEŠ, Vladimír; KLÍMA, Karel. Srovnávací ústavní právo. 5. vydání. Praha: Wolters Kluwer, 2015. ISBN 978-80-7478-687-7.

[6] BOHÁČEK, Martin, MACHŮ Matěj. Základy izraelského obchodního práva s důrazem na ochranu duševního vlastnictví. Praha: Wolters Kluwer, 2016. ISBN 978-80-7552-038-8.

[7] CASPI, Zvi. Small Claim Court. In KAPLAN, Alon (general editor) a kol. Israeli Business Law. Haag: Kluwer Law International, 1996. ISBN 90-411-0323-6.

[8] FRIEDMANN, Daniel. Consequences of Illegality under the Israeli Contract Law (General Part) 1973. The International and Comparative Law Quarterly, ročník. 33, č. 1. Cambridge University Press, 1984.

[9] GOLDSTEIN, Stephen; BAUM, Ido; KARAKO-EYAL, Nili; MERIN, Yuval. Civil Procedure in Israel. New York: Wolters Kluwer, 2013. ISBN 90-411-5163-X.

[10] JAKL, Ladislav. Metodologie vědy a výzkumu se zaměřením na oblast práv k průmyslovému a jinému duševnímu vlastnictví. Praha: Metropolitan University Prague Press, 2015. ISBN 978-80-87956-24-3.

[11] KRITZER, Albert; EISELEN, Sieg; BUTLER, Allison; MAZZOTTA, Francesco. International Contract Manual, Volume 3. New York: Thomson Reuters, 2014. ISBN 9780314964366.

[12] LISS, Eran, ADIN, Dan. Intellectual property law and practise in Israel. Oxford University Press, Inc., 2012. ISBN 978-019-9917-419.

[13] LUNNEY, Mark; OLIPHANT, Ken. Tort Law: Text and Materials. 5. vydání. Oxford: Oxford University Press, 2013. ISBN 978-0199655380. 
[14] MACHŮ, Matěj. Smíšené právní systémy a právo duševního vlastnictví: Systém práva duševního vlastnictví na Filipínách. Acta MUP - Právní ochrana duševního vlastnictví. Praha: Metropolitan University Prague Press, č. 1/2014.

[15] PALMER, Vernon. Mixed Jurisdictions Worldwide: The Third Legal Family. 2. vydání. New York: Cambridge University Press, 2014. ISBN: 978-0521768573.

[16] SHALEV, Gabriela; LERER, Lynn. Contract Law in Israel. Alphen aan den Rijn: Kluwer Law International, 2014. ISBN 90-411-5425-6.

[17] SHAPIRA, Amos. Introduction to the Law of Israel. Haag: Kluwer, 1995. ISBN 9065448357.

\subsection{ONLINE ZDROJE}

[18] Články. Lidovky.cz: Rozhovor s velvyslancem Státu Izrael Danielem Meronem pro deník lidovky.cz [online]. Publikováno: 19.3.2017. [cit. 27.3.2017]. Dostupné z: http://byznys.lidovky.cz/skoro-vsechny-taxiky-v-izraeli-jsou-skodovky-rika-novy-velvyslanec-1gy-/firmytrhy.aspx?c=A170317_172457_firmy-trhy_pave

[19] Ministerstvo zahraničních věcí České republiky. Asociační dohoda mezi členskými státy Evropské unie a Státem Izrael [online]. [cit. 01.01.2017]. Dostupné z: http://www.mzv.cz/public/50/a0/79/161530_14901_asso_agree_en.pdf

[20] SHALEV, Gabriela; HERMAN, Shael. A Source Study of Israel's Contract Codification. [online] Louisiana Law Review, číslo 35/1975. [cit. 29.5.2017] Dostupné z: http://digitalcommons.law.lsu.edu/cgi/viewcontent.cgi?article $=4117 \&$ context $=$ lalrev

[21] ADAR, Yehuda. Legal Engineering in Israeli Law: Codification and Unification of the Law of Remedies. [online]. [cit. 29.5.2017] Dostupné z: http://weblaw.haifa.ac.il/he/ Faculty/Adar/Publications/LEGAL\%20ENGINEERING\%20IN\%20REMEDIES.pdf

[22] Autorský zákon z roku 2007 In: Nevo. [online]. [cit. 27. 3. 2017] Dostupné z: https://www.nevo.co.il/law_html/Law01/999_853.htm

[23] WIPO. Aktuální přehled přistoupivších států - Pařížská úmluva. [online]. Dostupné z: http://www.wipo.int/treaties/en/ShowResults.jsp?treaty_id = 2

[24] Patentový zákon z roku 1967. In: Nevo. [online]. [cit. 27. 3. 2017] Dostupné z: https://www.nevo.co.il/law_html/Law01/P187_002.htm

[25] WIPO. Aktuální seznam přistoupivších států - PCT. [online]. Dostupné z: http://www.wipo.int/pct/en/pct_contracting_states.html.

[26] Odkaz pro vstup do databází dle jednotlivých ochranných institutů na stránkách IPÚ. [online]. [cit .27. 3. 2017] Dostupné z: http://www.justice.gov.il/En/Units/ILPO/ About/Pages/default.aspx

[27] Aktuální informace o poplatcích na stránkách IPÚ [online]. Dostupné z: https://ecom. gov.il/Counter/general/homepage.aspx ?counter $=14 \&$ catalog $=2 \&$ category $=$ patents $\&$ language $=\mathrm{e}$ 
[28] Designová ustanovení - předpis o patentech a průmyslových vzorech z roku 1924. In: WIPO lex. [online]. [cit. 27. 3. 2017] Dostupné z: http://www.wipo.int/wipolex/en/text.jsp? file_id $=202111$

[29] Designová pravidla z roku 1925. In: WIPO lex. [online]. [cit. 27. 3. 2017] Dostupné z: http://www.wipo.int/wipolex/en/text.jsp?file_id $=343760$

[30] Předpis o ochranných známkách z roku 1972. In: WIPO lex. [online]. [cit. 27. 3. 2017] Dostupné z: http://www.wipo.int/wipolex/en/text.jsp?file_id $=341340$

[31] Zákon o trestním řízení z roku 1982 In: WIPO lex. [online]. [cit. 27. 3. 2017] Dostupné z: http://www.wipo.int/wipolex/en/text.jsp?file_id $=367172$

[32] Zákon o obchodních mimosmluvních deliktech z roku 1999 In: WIPO lex. [online]. [cit. 27. 3. 2017] Dostupné z: http://www.wipo.int/wipolex/en/text.jsp?file_id = 128056

[33] Zákon o ochraně spotřebitele $\mathrm{z}$ roku 1981 In: WIPO lex. [online]. [cit. 27. 3. 2017] Dostupné z: http://www.wipo.int/wipolex/en/text.jsp?file_id = 128084

[34] Články. Mondag.com. Unjust Enrichment (Restitution) - the Elements Necessary to Establish a Claim for Unjust Enrichment. [online]. Publikováno: 21.1.2005. [cit. 01.01.2017] Dostupné z: http://www.mondaq.com/x/30533/Product + Liability + Safety/Unjust + Enrichment + Restitutionthe + Elements + Necessary + to + Establish + a + Claim + for + Unjust + Enrichment.

\subsection{JUDIKATURA}

[35] Rozhodnutí Nejvyššího soudu v Jeruzalémě 6821/93 United Mizrachi Bank Ltd. proti Migdal Cooperative Village In: Nevo [online]. [cit. 27. 3. 2017] Dostupné z: www.nevo.co.il/Psika_word/elyon/PADI-NH-4-221-L.doc

[36] Rozhodnutí Nejvyššího soudu v Jeruzalémě 5768/94 A.Sh.I.R. Importation Manufacture and Distribution et al. proti Forum Accessories and Consumer Products et al. In: Nejvyšší soud v Jeruzalémě [online]. [cit. 27. 3. 2017] Dostupné z: http://elyon1. court.gov.il/files/94/680/057/G04/94057680.g04.pdf

[37] Rozhodnutí Nejvyššího soudu v Jeruzalémě 513/89 Interlego S.A. proti Exin Lines Bros. S.A., et al. In: Nevo [online]. [cit. 27. 3. 2017] Dostupné z: www.nevo.co.il/ Psika_word/elyon/PADI-NG-4-133-L.doc

[38] Rozhodnutí Nejvyššího soudu v Jeruzalémě 311/78 Miarah Nasim proti Howard Hania In: Nevo [online]. [cit. 27. 3. 2017] Dostupné z: www.nevo.co.il/Psika_word/elyon/PADI-LD2-505-L.doc

[39] Rozhodnutí Nejvyššího soudu v Jeruzalémě 723/74 Israel Electric Company Ltd. proti Ha‘aretz Newspaper Ltd In: Nejvyšší soud v Jeruzalémě [online]. [cit. 27. 3. 2017] Dostupné z: http://elyon1.court.gov.il/files_eng/74/230/007/Z01/74007230.z01.pdf 
[40] Rozhodnutí Nejvyššího soudu v Jeruzalémě 14/86 La'or proti The Israel Film and Theater Council In: Lawdata.co.il [online]. [cit. 27. 3. 2017] Dostupné z: http://www.lawdata. co.il/printDoc.asp $? \mathrm{c}=566490 \&$ mador $=$ psak $\& I$ IskurHokIndx $=\&$ IskurHokSeif $=\&$ note $=\& \mathrm{dt}=$ 1488844875000

[41] Rozhodnutí Nejvyšší soudu v Jeruzalémě 9191/03 V\&S Vin \& Spirt Aktiebolag proti Absolute Shoes Ltd In: Nevo [online]. [cit. 27. 3. 2017] Dostupné z: http://www.nevo.co.il/ Psika_word/elyon/0309191.doc

[42] Rozhodnutí Oblastního soudu v Tel Avivu 476/82 Orlogad Ltd. proti Registrar of Trade Mark In: Lawdata.co.il [online]. [cit. 27. 3. 2017] Dostupné z: http://www.lawdata.co.il/printDoc.asp $? \mathrm{c}=484763 \&$ mador $=$ psak\&IskurHokIndx $=$ \&IskurHokSeif $=\&$ note $=\& \mathrm{dt}=148884510$ 0000

[43] Řízení před Oblastním soudem v Tel Avivu 729/80 Moshe Dolev proti Abraham Amgar In: University of Haifa [online]. [cit. 27. 3. 2017] Dostupné z: http://moodle.haifa.ac.il/mod/resource/view.php?id $=28702 \&$ redirect $=1$.

[44] Rozsudek ESD č. C-283/01 ve věci Shield Mark BV proti Joost Kist h.o.d.n. Memex In: EUR-lex [online]. [cit. 27. 3. 2017] Dostupné z: http://eur-lex.europa.eu/legalcontent/EN/TXT/?uri $=$ CELEX\%3A62001CJ0283

[45] Rozhodnutí Nejvyššího soudu v Jeruzalémě 2673/04 Coffee To Go Ltd. proti Israel Shaked In: Nejvyšší soud $\mathrm{v}$ Jeruzalémě [online]. [cit. 27. 3. 2017] Dostupné z: http://elyon1.court.gov.il/files/04/730/026/Z07/04026730.z07.pdf

[46] Rozhodnutí Nejvyššího soudu v Jeruzalémě 3559/02 Toto Zahav Members Club Ltd. proti The Sports Gambling Council In: Nejvyšší soud v Jeruzalémě [online]. [cit. 27. 3. 2017] Dostupné z: http://elyon1.court.gov.il/files/02/590/035/N18/02035590.n18.pdf

[47] Rozhodnutí Nejvyššího soudu v Jeruzalémě 8485/08 FA Premier League et al. proti the Israeli Sporting Gambling Association In: Nejvyšší soud v Jeruzalémě [online]. [cit. 27. 3. 2017] Dostupné z: http://elyon1.court.gov.il/files/08/850/084/h02/08084850.h02.pdf

[48] Rozhodnutí Nejvyššího soudu v Jeruzalémě 571/68 David Yanai proti El Mansfeld In: Nevo [online]. [cit. 27. 3. 2017] Dostupné z: https://www.nevo.co.il/psika_html/elyon/e2368000571.pdf

[49] Rozhodnutí Oblastního soudu v Tel Avivu 1253/05 H.Stern Comerció e Industria S.A. et al., proti A. Arnil Ltd et al. In: Nevo [online]. [cit. 27. 3. 2017] Dostupné z: https://www.nevo.co.il/psika_html/mechozi/ME-05-1253-583.htm

Toto dílo lze užít v souladu s licenčními podmínkami Creative Commons BY-SA 4.0 International (http://creativecommons.org/licenses/by-sa/4.0/legalcode). 
